\title{
Synthesis and evaluation of novel naphthol diazenyl scaffold based Schiff bases as potential antimicrobial and cytotoxic agents against human colorectal carcinoma cell line (HT-29)
}

\author{
Harmeet Kaur ${ }^{1}$, Jasbir Singh ${ }^{2}$ and Balasubramanian Narasimhan ${ }^{1 *}$ (D)
}

\begin{abstract}
Background: In search of new antimicrobial and cytotoxic agents, a series of new naphthol diazenyl scaffold based Schiff bases (NS1-NS23) was efficiently synthesized by condensation of 2-hydroxy naphthaldehyde azo dyes with various substituted aromatic/heteroaromatic/aliphatic amines.

Methodology: The synthesized derivatives were characterized by various physicochemical and spectral techniques and assessed for in vitro antimicrobial and cytotoxic potential against human colorectal carcinoma cell line (HT-29). The active derivatives were further evaluated for their apoptotic potential by Annexin-V/propidium iodide double staining assay using flow cytometer and analyzed for cell-cycle arrest studies.

Results and conclusion: The derivative $\mathbf{N S}-\mathbf{2}$ was found maximum active against $E$. coli, S. enterica and B. subtilis. The derivatives NS-12, NS-15, NS-21, and NS-23 showed maximum antifungal activity against $A$. fumigatus. The maximum cytotoxicity was observed from the derivatives $\mathbf{N S}-\mathbf{2}, \mathbf{N S}-\mathbf{8}, \mathbf{N S}-\mathbf{2 1}$, and $\mathbf{N S}-\mathbf{2 3}$ towards HT-29 cell line with $\mathrm{IC}_{50}$ between 4 and $19 \mu \mathrm{g} / \mathrm{ml}$. More than $90 \%$ and $62 \%$ of the cells were found in the apoptotic phase on treatment with NS-2 and NS-21 respectively in comparison to the 68\% for doxorubicin. Further, these derivatives arrested the cell growth in $\mathrm{S}$ and $\mathrm{G} 2 / \mathrm{M}$ phase of the cell cycle.
\end{abstract}

Keywords: Schiff base, Antimicrobial, Diazenyl, Apoptosis, Cell cycle

\section{Background}

In spite of the development of new medicine, the cancer is still the leading cause of death worldwide and recognized as the uncontrolled and abnormal growth of the cells which is considered a multistep-multifaceted process involving a sequence of events and often accompanied with the suppression of immune system [1-3]. Patients with cancer are also at the increased risks of microbial infections as compared to the normal

\footnotetext{
*Correspondence: naru2000us@yahoo.com

${ }^{1}$ Faculty of Pharmaceutical Sciences, Maharshi Dayanand University, Rohtak 124001, India

Full list of author information is available at the end of the article
}

persons generally due to easy access of microorganisms as a result of interrupted epithelial barriers, compromised host defense, the absence of neutrophils, and shifts in the microbial flora [4-6]. Therefore, most patients diagnosed with cancer are also recommended with the antibiotics $[7,8]$.

Colorectal cancer (CRC), the second most common cancer in females and the third in males is a soft tissue neoplasm which arises from the lining of the large intestine (colon and rectum) [9-11]. The successful treatment of several malignancies including colorectal cancer is limited by lack of the complete eradication of the tumor cell population, the development of resistance to the chemotherapeutic agents probably through the 
modulation of anti-apoptotic or proliferative proteins of the survival cells and increased risk of microbial infections due to the suppression of host immune system [1214]. For instance, Escherichia coli and Salmonella species have been reported as the possible cause of microbial infections in colorectal cancer [15-17]. The most commonly used therapeutic agents like oxaliplatin, cisplatin, fluoropyrimidines, irinotecan, in the treatment of colon cancer, have been shown to induce resistance in cancer cell killing resulting in the continued and rapid increase in the number of cancer cells $[18,19]$.

The induction of apoptosis as a result of DNA damage in cancer cells represents an effective strategy for preventing tumor growth [20]. The discovery of new molecules capable of reinstating the cellular mechanisms responsible for the induction of apoptosis in colon cancer cells and simultaneously having the potential to reduce the probability of microbial infections may provide additional benefits [21]. In the current research, we have planned the synthesis of novel hybridized molecules having cytotoxic and antimicrobial potential together.

Schiff's bases have gained a lot of interest in the pharmaceutical and medicinal field in the past years [22]. They are the condensation products of carbonyl compounds with the primary amines having structural feature azomethine group $(-\mathrm{HC}=\mathrm{N}-)$ substituted by various alkyl, aryl, cycloalkyl, or heteroaryl groups [23]. Schiff's bases exhibit a broad spectrum of biological activities, comprising of antibacterial, antifungal, antiviral, antimalarial, anti-inflammatory and antipyretic properties [24]. Recently several reports have cited the potential of Schiff bases as cytotoxic agents [25-27]. Similarly, diazenyl compounds have also attracted the attention of researchers due to their extensive biological properties. Several diazenyl compounds (i.e. diazeniumdiolate prodrugs, diazenecarboxamides, diazenyl complexes etc.) have been already reported for their cytotoxic potential against different cancer cell lines in recent years [28-30]. These derivatives also reported having antimicrobial activity [31,32]. The antimicrobial and cytotoxic effects of naphthol ring have already been disclosed [33, 34]. Hence, hybridization of the naphthol diazenyl ($\mathrm{N}=\mathrm{N}-)$ scaffold with the Schiff base $(\mathrm{CH}=\mathrm{N})$ can be a useful approach for the synthesis of new and effective compounds to act against both these diseases.

In this direction, we have synthesized novel naphthol diazenyl scaffold containing Schiff bases with various aromatic/heteroaromatic and aliphatic moieties and screened for their antimicrobial and cytotoxic potentials against human colorectal carcinoma cell line HT-29. The active agents were further evaluated for their apoptosis induction potential and cell cycle arrest studies. These dual-action novel derivatives with the advantage of cytotoxic potential against colon cancer and antimicrobial action from the same molecule may become highly desirable molecules therapeutically.

\section{Results and discussion \\ Chemistry}

The synthetic scheme of naphthol diazenyl scaffold based Schiff bases is presented in Fig. 1. The different mono or di-substituted anilines in the presence of hydrochloric acid were diazotized with sodium nitrite, subsequently coupled with an ethanolic alkaline solution of 2-hydroxy naphthaldehyde to give azo dyes (ND1-ND5). The aldehyde group in naphthaldehyde azo dyes on reaction with different aromatic/heteroaromatic/aliphatic amines in the presence of catalytic amount of acetic acid resulted in $\mathbf{1 8}$ diazenyl Schiff bases (NS-1 to NS-23) as given in Table 1. The structural confirmation of the target compounds was carried out by FTIR, UV-vis, NMR, mass spectroscopy, and elemental analysis. The thiophene substituted amines used in the reaction were prepared by the reported Gewald procedure [35]. The derivatives NS-3, NS-17, NS-18, NS-19, and NS-20 have not been mentioned in the scheme as these derivatives did not meet the purity requirements for structural agreement by spectral techniques.

\section{UV spectroscopy}

The electronic absorption spectra of 2-hydroxy naphthaldehyde based dyes (ND1-ND-5) and diazenyl Schiff bases (NS1-NS23) were recorded in polar solvent methanol at the room temperature at the concentration of $1 \times 10^{-5} \mathrm{M}$ from the range of $200-800 \mathrm{~nm}$. The scans and data have been presented in Fig. 2 and Table 2 respectively. The dyes (ND1-ND5) generally show absorption in the UV-visible range due to the presence of chromophore groups [36]. The absorption bands in the UV spectrum of dyes have been observed at 470-495 nm, $356-358 \mathrm{~nm}, 316 \mathrm{~nm}$ along with relatively minor bands in the range of $250-290 \mathrm{~nm}$. The diazenyl Schiff bases have shown absorption maximum $\left(\lambda_{\max }\right)$ at $430-497 \mathrm{~nm}$, $340-397 \mathrm{~nm}, 330 \mathrm{~nm}, 305-315 \mathrm{~nm}$ and small bands in the range of $250-290 \mathrm{~nm}$. The $\lambda_{\max }$ may be assigned to $\mathrm{n}-\pi^{*}$ and $\pi-\pi^{*}$ transitions in the chromophoric $-\mathrm{N}=\mathrm{N}-$ group, $\mathrm{C}=\mathrm{O}$ group and other unsaturated groups present in the aromatic rings. The increased oxygenation on the ring generally results in bathochromic shifts. The dyes with nitro and carboxy groups substitution have shown absorption maximum at a higher wavelength as compared to the dyes with methyl group substitution. This may be attributed to the extended conjugated system due to the nitro and carboxyl groups. 
<smiles>[R2]c1ccccc1N</smiles>

Substituted aniline derivative<smiles>[R]c1ccccc1/N=N/c1cc2ccccc2c(C=O)c1O</smiles>

Naphthol aldehyde diazenyl scaffold

$$
\begin{aligned}
& \text { ND1; } \mathrm{R}_{1}=4-\mathrm{COOH}, \mathrm{R}_{2}=\mathrm{H} \\
& \text { ND2; } \mathrm{R}_{1}=2-\mathrm{Cl}, \mathrm{R}_{2}=5-\mathrm{Cl} \\
& \text { ND3; } \mathrm{R}_{1}=2-\mathrm{CH}_{3}, \mathrm{R}_{2}=4-\mathrm{CH}_{3} \\
& \text { ND4; } \mathrm{R}_{1}=2-\mathrm{NO}_{2}, \mathrm{R}_{2}=4-\mathrm{Cl} \\
& \text { ND5; } \mathrm{R}_{1}=2-\mathrm{Cl}, \mathrm{R}_{2}=4-\mathrm{NO}_{2}
\end{aligned}
$$

a, b

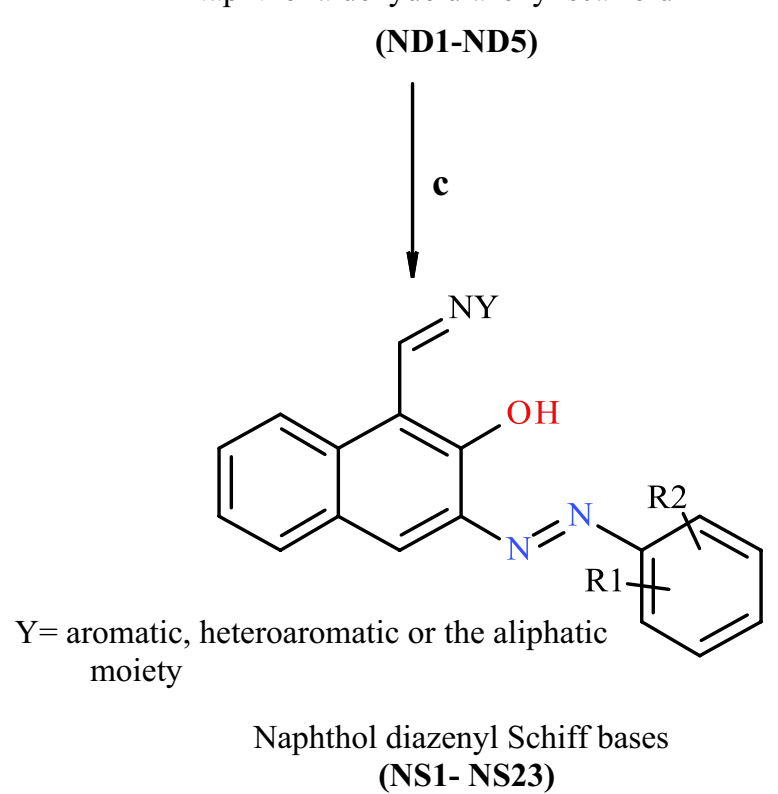

Reagents and conditions: a) sodium nitrite, $\mathrm{HCl}, 0{ }^{\circ} \mathrm{C}$, b) 2- hydroxy 1- napthaldehyde, $\mathrm{C}_{2} \mathrm{H}_{5} \mathrm{OH}, \mathrm{Na}_{2} \mathrm{CO}_{3}$, $\left.0{ }^{\circ} \mathrm{C}, \mathrm{c}\right)$ Aromatic/heteroaromatic/aliphatic amines $\left(\mathrm{NH}_{2} \mathrm{Y}\right)$, acetic acid, reflux for $7-8 \mathrm{~h}$.

Fig. 1 Synthetic methodology for naphthol diazenyl scaffold based Schiff bases

\section{IR spectroscopy}

The IR spectrum of synthesized compounds was determined by FTIR-attenuated reflectance (ATR) method. The dyes (ND1-ND5) exhibited $\mathrm{C}=\mathrm{O}$ stretching vibration due to aldehyde group at $1630-1635 \mathrm{~cm}^{-1}$. The diazenyl Schiff bases exhibited $-\mathrm{CH}=\mathrm{N}-$ absorption peak in the range of $1600-1636 \mathrm{~cm}^{-1}$. The $\mathrm{C}=\mathrm{O}$ stretch due to the carboxyl group has been observed at 1675$1781 \mathrm{~cm}^{-1}$. The compounds having ester group exhibited another $-\mathrm{C}=\mathrm{O}$ stretch at the $1721-1730 \mathrm{~cm}^{-1}$. The $\mathrm{C}=\mathrm{C}-$ a stretch of the aromatic rings appeared at 1565$1595 \mathrm{~cm}^{-1}$. The phenolic -OH group generally appeared as a broad peak in the range of $3650-3250 \mathrm{~cm}^{-1}$. The aldehydic $=\mathrm{C}-\mathrm{H}$ group exhibited weak bands around $2850 \mathrm{~cm}^{-1}$ and $2750 \mathrm{~cm}^{-1}$. The presence of a band at 1465-1425 $\mathrm{cm}^{-1}$ confirmed the presence of azo linkage. The other peaks observed are the Ar-O stretching at $1100-1280 \mathrm{~cm}^{-1},-\mathrm{C}=\mathrm{C}-$ bending at $680-760 \mathrm{~cm}^{-1}$, the $\mathrm{C}-\mathrm{N}$ stretching between $1000-1350 \mathrm{~cm}^{-1}$ and $\mathrm{C}-\mathrm{S}$ stretching at $702 \mathrm{~cm}^{-1}$ and $617 \mathrm{~cm}^{-1}$. The aliphatic
$\mathrm{C}-\mathrm{H}$ stretch in methyl group was observed at 2850$3000 \mathrm{~cm}^{-1}$. The $\mathrm{NO}_{2}$ stretch confirmed by the two strong bands at $1280-1380 \mathrm{~cm}^{-1}$ and $1465-1520 \mathrm{~cm}^{-1}$. The bands in the range of $550-1050 \mathrm{~cm}^{-1}$ have been assigned to the $\mathrm{C}-\mathrm{X}$ (halogen) absorption.

\section{NMR Spectroscopy}

The ${ }^{1} \mathrm{H}$ NMR and ${ }^{13} \mathrm{C}$ NMR spectrum of the compounds were taken in $\mathrm{CDCl}_{3} / \mathrm{DMSO}$ solvents. The dyes (ND1-ND5) exhibited an aldehydic proton peak at $\delta$ 10.2-10.5 ppm. The Schiff bases exhibited a singlet at $\delta$ 8.5-9.8 ppm indicating the presence of $\mathrm{CH}=\mathrm{N}$ proton with the complete disappearance of the peak at $\delta 10.2-$ 10.5. The proton of the hydroxyl group on the 2 nd position of the naphthalene ring generally appeared in the range of $\delta 12.5-16 \mathrm{ppm}$. The signals of the aromatic protons have been observed in the range of $\delta 6.8-8.5 \mathrm{ppm}$. The protons of the ethoxy group produced a classic triplet-quartet signal pattern at $\delta 1.30-1.49$ ppm and 4.3$4.9 \mathrm{ppm}$ respectively. The proton signal of the methylene 
Table 1 Structure of various naphthol diazenyl based Schiff bases

\begin{tabular}{|c|c|c|c|c|}
\hline S. No & Compound & $\mathrm{R}_{1}$ & $\mathrm{R}_{2}$ & $\mathrm{Y}$ \\
\hline 1 & NS-1 & $4-\mathrm{COOH}$ & $\mathrm{H}$ & \\
\hline 2 & NS-2 & $4-\mathrm{COOH}$ & $\mathrm{H}$ & \\
\hline 3 & NS-4 & $4-\mathrm{COOH}$ & $\mathrm{H}$ & \\
\hline 4 & NS-5 & $2-\mathrm{Cl}$ & $5-\mathrm{Cl}$ & \\
\hline 5 & NS-6 & $2-\mathrm{Cl}$ & $5-\mathrm{Cl}$ & \\
\hline 6 & NS-7 & $2-\mathrm{CH}_{3}$ & $4-\mathrm{CH}_{3}$ & \\
\hline 7 & NS-8 & $2-\mathrm{Cl}$ & $5-\mathrm{Cl}$ & \\
\hline 8 & NS-9 & $2-\mathrm{Cl}$ & $5-\mathrm{Cl}$ & \\
\hline 9 & NS-10 & $2-\mathrm{Cl}$ & $5-\mathrm{Cl}$ & \\
\hline 10 & NS-11 & $2-\mathrm{Cl}$ & $5-\mathrm{Cl}$ & \\
\hline 11 & NS-12 & $2-\mathrm{Cl}$ & $5-\mathrm{Cl}$ & \\
\hline 12 & NS-13 & $4-\mathrm{COOH}$ & $\mathrm{H}$ & \\
\hline 13 & NS-14 & $2-\mathrm{NO}_{2}$ & $4-\mathrm{Cl}$ & \\
\hline 14 & NS-15 & $2-\mathrm{NO}_{2}$ & $4-\mathrm{Cl}$ & \\
\hline 15 & NS-16 & $2-\mathrm{Cl}$ & $4-\mathrm{NO}_{2}$ & \\
\hline 16 & NS-21 & $2-\mathrm{NO}_{2}$ & $4-\mathrm{Cl}$ & \\
\hline 17 & NS-22 & $2-\mathrm{Cl}$ & $5-\mathrm{Cl}$ & \\
\hline 18 & NS-23 & $4-\mathrm{COOH}$ & $\mathrm{H}$ & \\
\hline
\end{tabular}

group as in the case of NS-2 and NS-11 appeared as a singlet at 4.76-4.79 $\mathrm{ppm}$. The furan ring presented three peaks as doublets at $\delta 6.23-6.37 \mathrm{ppm}, 6.53-6.98 \mathrm{ppm}$, and 7.23-7.27 ppm respectively. The protons of the methylene groups of the aliphatic chain in NS-21, NS22, and NS-23 have been observed as the triplets at $\delta$ $1.90-2.13 \mathrm{ppm}, \delta 2.32-2.54 \mathrm{ppm}$, and $\delta 3.66-3.76 \mathrm{ppm}$ respectively. The proton of the carboxyl group appeared in the range of $\delta 11-13 \mathrm{ppm}$. The protons of the saturated carbons of the cyclohexenyl ring appeared as two multiplets at $\delta 2.73-2.84\left(4 \mathrm{H}, 2 \mathrm{CH}_{2}\right)$ and $\delta 1.43-1.85(4 \mathrm{H}$, $2 \mathrm{CH}_{2}$ ). The carbon signals of the aromatic carbons in ${ }^{13} \mathrm{C}$ NMR spectrum of Schiff bases observed between 109 and $156 \mathrm{ppm}$. The ${ }^{13} \mathrm{C}$ NMR peaks at $165-177 \mathrm{ppm}$ accounted for the carbonyl group. The carbon of the imine group was observed between 160 and $165 \mathrm{ppm}$. The ethoxy carbons appeared at the 60-63 ppm and $14-21 \mathrm{ppm}$ respectively. The peak in the range of 54-57 ppm represented the methylene carbons of NS-2 and NS-11. The carbon signals of saturated carbons of the cylohexenyl ring appeared in the range of $20-28 \mathrm{ppm}$. The ${ }^{1} \mathrm{H}$ and ${ }^{13} \mathrm{C}$ NMR spectra of most active compounds has been provided as the Additional file 1.

\section{Mass spectroscopy and $\mathrm{CHNO} / \mathrm{S}$ analysis}

The final confirmation of the synthesized compounds was done by mass spectroscopy. The diazenyl Schiff bases exhibited $\mathrm{M}^{+}$(molecular ion peak) in positive chemical ionization mode. The \% of $\mathrm{C}, \mathrm{O}, \mathrm{N}, \mathrm{H}$ and $\mathrm{S}$ in the target compounds was within defined limits.

\section{Antimicrobial results}

The synthesized derivatives NS1 to NS23 were evaluated for their antimicrobial potential in terms of minimum inhibitory concentration (MIC) and minimum bactericidal concentration $(\mathrm{MBC}) /$ minimum fungicidal concentration (MFC) values in $\mu \mathrm{g} / \mathrm{ml}$ against standard drugs cefotaxime (antibacterial) and fluconazole (antifungal) and the results have been presented in Tables 3 and 4 respectively. Most of the synthesized derivatives had shown maximum activity against $E$. coli with MIC ranging from 1.95 to $31.25 \mu \mathrm{g} / \mathrm{ml}$. These derivatives acted as bacteriostatic agents as well as bactericidal agents with $\mathrm{MBC}$ values ranging from 7.81 to $31.25 \mu \mathrm{g} /$ ml. NS-2 and NS-8 had shown the highest activity against $S$. enterica $(\mathrm{MIC}=1.95-3.91 \mu \mathrm{g} / \mathrm{ml}) . \mathbf{N S}-2$ was active against maximum bacterial strains but possessed very less activity against fungal strains whereas NS-8 showed maximum bactericidal activity especially against S. enterica $(\mathrm{MBC}=1.95 \mu \mathrm{g} / \mathrm{ml})$. NS-15 was most active against E. coli and Aspergillus fumigatus both. NS-4, NS5, and NS-7 were found active but against only E. coli. All synthesized derivatives have shown moderate activity against Staphylococcus aureus. The maximum activity was observed for the derivatives NS-12, NS-21 and NS-23 against $A$. fumigatus (MIC $=3.91-7.82 \mu \mathrm{g} / \mathrm{ml}$ and $\mathrm{MBC}=3.91-15.62 \mu \mathrm{g} / \mathrm{ml})$. The most of the synthesized derivatives found inactive against fungal strain Aspergillus niger with maximum activity shown by the derivative NS-15 with the MIC of $15.62 \mu \mathrm{g} / \mathrm{ml}$. From the above 

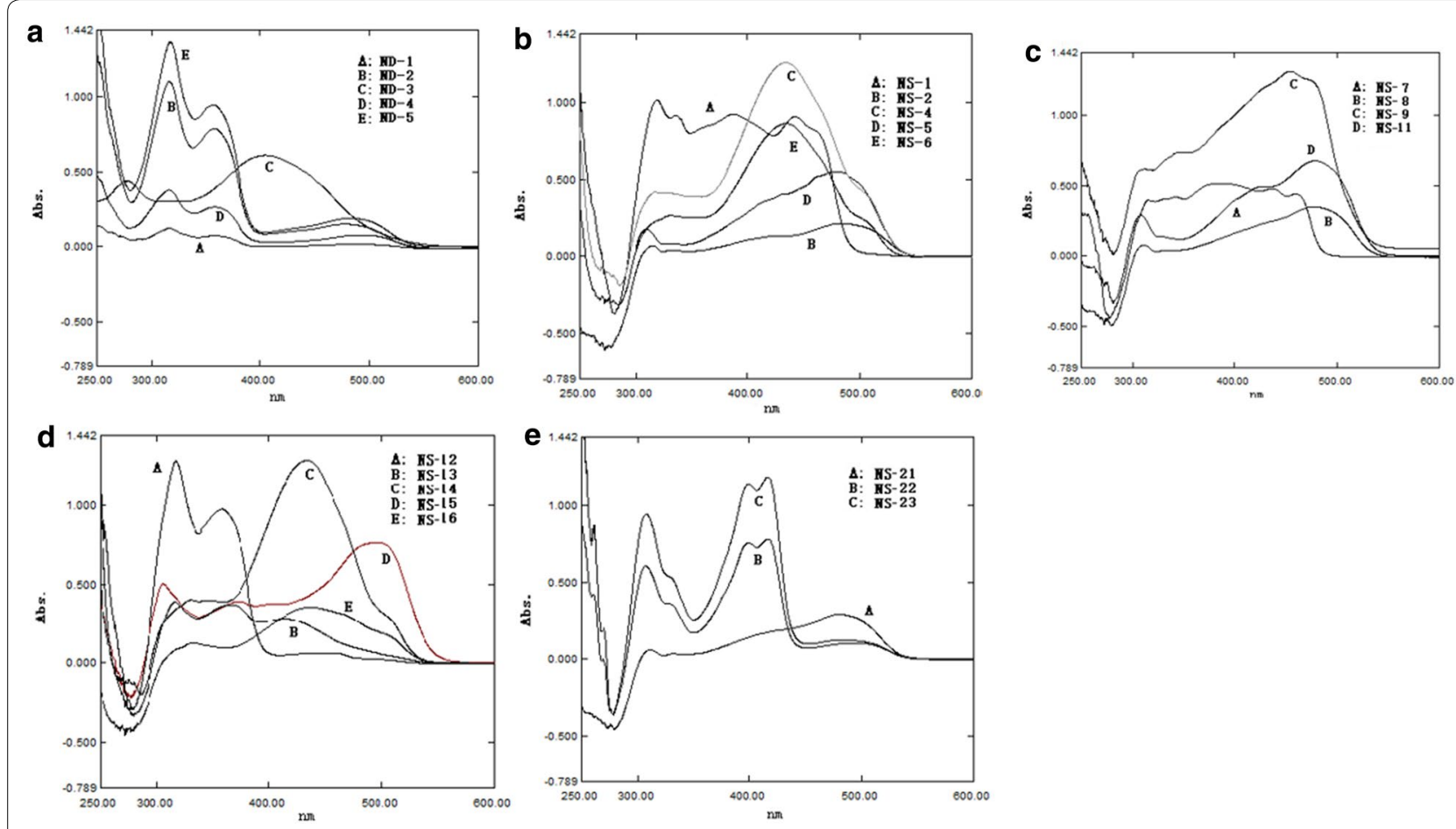

Fig. 2 Electronic absorption spectra of dyes (ND1-ND-5) and naphthol diazenyl scaffold based Schiff bases (NS1-NS-23) in methanol at concentration of $1 \times 10^{-5} \mathrm{M}$

Table 2 Absorption maximum ( $\lambda_{\max }$ ) of dyes and naphthol diazenyl scaffold based Schiff bases

\begin{tabular}{llllllll}
\hline Comp. & Wavelength $\left(\boldsymbol{\lambda}_{\max }\right)$ & Comp. & Wavelength $\left(\boldsymbol{\lambda}_{\max }\right)$ & Comp. & Wavelength $\left(\boldsymbol{\lambda}_{\max }\right)$ & Comp. & Wavelength $\left(\boldsymbol{\lambda}_{\max }\right)$ \\
\hline ND-1 & $482,358,316,289$ & NS-1 & $442,387,335,318$ & NS-9 & $453,348,312,275,272$ & NS-16 & $437,333,283,265$ \\
ND-2 & $477,357,316,254$ & NS-2 & $481,340,331,315$ & NS-10 & $432,335,302,275$ & NS-21 & $497,416,399,307,259$ \\
ND-3 & $404,323,279,275$ & NS-4 & $434,350,328,317,280,270$ & NS-11 & $477,340,329,308$, & NS-22 & $481,339,330,312$ \\
ND-4 & $495,358,339,316$ & NS-5 & $479,331,309,270$ & NS-12 & $458,434,358,317,254$ & NS-23 & $482,415,399,308,269$ \\
ND-5 & $482,357,316$ & NS-6 & $434,350,340,330,280,270$ & NS-13 & $414,366,316,283$ & & \\
- & - & NS-7 & $460,436,389,341,315,254$ & NS-14 & $434,350,340,330,280$ & & \\
- & - & NS-8 & $477,340,333,311,275,260$ & NS-15 & $496,403,372,306,269$ & & \\
\hline
\end{tabular}

results, it is evident that the naphthol diazenyl scaffold has been essential for activity against E. coli. Mostly synthesized derivatives have shown maximum activity against E. coli. By the introduction of furfuryl ring at the naphthol diazenyl scaffold with carboxyl group substitution has dramatically increased the antibacterial activity. The presence of two thiophene rings in the molecule significantly increases the activity towards S. enterica (NS-8). Introduction of the aliphatic chain having three carbon atoms with a carboxyl group at the diazenyl scaffold expressively enhances the activity towards $A$. fumigatus which is decreased by substitution of two chloro groups at the diazenyl ring.
The most active derivatives (NS-1, NS-2, NS-4, NS-6, NS-8, NS-11, NS-12, NS-14, NS-15, NS-16, NS-21 and NS-23) based on the MIC and MBC values and based on the structural differences were further selected for cytotoxicity towards human colorectal carcinoma cell line (HT-29).

\section{Declines in HT-29 cell viability following exposure to test compounds}

The cytotoxic potential of the most active derivatives (as mentioned in the above section) was evaluated by MTT (3,4,5-dimethylthiazol-2-yl)-2-5-diphenyltetrazolium 
Table 3 Determination of MIC values $(\mu \mathrm{g} / \mathrm{ml})$ of naphthol diazenyl scaffold based Schiff bases

\begin{tabular}{|c|c|c|c|c|c|c|}
\hline Compound & E. coli & B. subtilis & S. enterica & S. aureus & A. niger & A. fumigatus \\
\hline \multicolumn{7}{|l|}{ MIC ( $\mu \mathrm{g} / \mathrm{ml})$} \\
\hline NS-1 & 15.62 & 62.5 & 31.25 & 62.5 & 62.5 & 31.25 \\
\hline NS-2 & 3.91 & 3.91 & 1.95 & 31.25 & 125 & 125 \\
\hline NS-4 & 3.91 & 250 & 62.5 & 125 & 125 & 125 \\
\hline NS-5 & 7.81 & 62.5 & 31.25 & 125 & 125 & 125 \\
\hline NS-6 & 31.25 & 125 & 31.25 & 125 & 125 & 125 \\
\hline NS-7 & 3.91 & 250 & 62.5 & 62.5 & 125 & 125 \\
\hline NS-8 & 3.91 & 31.25 & 1.95 & 62.5 & 125 & 125 \\
\hline NS-9 & 15.62 & 125 & 62.5 & 62.5 & 125 & 125 \\
\hline NS-10 & 31.25 & 15.62 & 31.25 & 62.5 & 125 & 125 \\
\hline NS-11 & 15.62 & 125 & 31.25 & 125 & 125 & 62.5 \\
\hline NS-12 & 31.25 & 62.5 & 31.25 & 62.5 & 31.25 & 3.91 \\
\hline NS-13 & 3.91 & 15.62 & 62.5 & 62.5 & 31.25 & 15.62 \\
\hline NS-14 & 3.91 & 62.5 & 62.5 & 125 & 125 & 125 \\
\hline NS-15 & 1.95 & 62.5 & 62.5 & 62.5 & 15.62 & 3.91 \\
\hline NS-16 & 3.91 & 62.5 & 125 & 125 & 125 & 125 \\
\hline NS-21 & 15.62 & 31.25 & 62.5 & 125 & 62.5 & 3.91 \\
\hline NS-22 & 31.25 & 7.82 & 31.25 & 125 & 125 & 125 \\
\hline NS-23 & 15.62 & 62.5 & 31.25 & 62.5 & 62.5 & 7.82 \\
\hline Cefotaxime & 3.91 & 3.91 & 1.95 & 31.25 & - & - \\
\hline Fluconazole & - & - & - & - & 7.81 & 15.62 \\
\hline
\end{tabular}

Table 4 Determination of MBC/MFC values $(\mu \mathrm{g} / \mathrm{ml})$ of naphthol scaffold based Schiff bases

\begin{tabular}{|c|c|c|c|c|c|c|}
\hline Compound & E. coli & B. subtilis & S. enterica & S. aureus & A. niger & A. fumigatus \\
\hline \multicolumn{7}{|c|}{ MBC/MFC ( $\mu \mathrm{g} / \mathrm{ml})$} \\
\hline NS-1 & 31.25 & 125 & 62.5 & 62.5 & 62.5 & 62.5 \\
\hline NS-2 & 7.81 & 15.62 & 7.81 & 31.25 & 125 & 125 \\
\hline NS-4 & 31.25 & 250 & 12.55 & 125 & 125 & 125 \\
\hline NS-5 & 7.81 & 62.5 & 62.5 & 125 & 125 & 125 \\
\hline NS-6 & 62.5 & 125 & 62.5 & 125 & 125 & 125 \\
\hline NS-7 & 15.62 & 250 & 62.5 & 125 & 125 & 125 \\
\hline NS-8 & 15.62 & 31.25 & 1.95 & 62.5 & 125 & 125 \\
\hline NS-9 & 125 & 125 & 125 & 125 & 125 & 125 \\
\hline NS-10 & 125 & 31.25 & 125 & 125 & 125 & 125 \\
\hline NS-11 & 31.25 & 125 & 31.25 & 125 & 125 & 62.5 \\
\hline NS-12 & 31.25 & 62.5 & 62.5 & 62.5 & 31.25 & 7.81 \\
\hline NS-13 & 7.81 & 62.5 & 125 & 62.5 & 31.25 & 15.62 \\
\hline NS-14 & 7.81 & 62.5 & 62.5 & 125 & 125 & 125 \\
\hline NS-15 & 15.62 & 125 & 62.5 & 62.5 & 31.25 & 15.62 \\
\hline NS-16 & 7.81 & 125 & 125 & 125 & 125 & 125 \\
\hline NS-21 & 15.62 & 62.5 & 62.5 & 125 & 62.5 & 3.91 \\
\hline NS-22 & 31.25 & 125 & 125 & 125 & 125 & 125 \\
\hline NS-23 & 15.62 & 125 & 62.5 & 62.5 & 62.5 & 7.81 \\
\hline Cefotaxime & 7.81 & 15.62 & 1.95 & 62.5 & - & - \\
\hline Fluconazole & - & - & - & - & 15.62 & 31.25 \\
\hline
\end{tabular}


bromide) assay which is based on the reduction of the yellow colored water-soluble tetrazolium dye MTT by the mitochondrial lactate dehydrogenase formed by the live cells to the formazan crystals, which display purple color upon dissolution into the suitable solvent. The intensity of the purple color is directly proportional to the number of viable cells and can be measured by spectrophotometer at $570 \mathrm{~nm}$. The HT-29 cells were treated with different concentrations of these derivatives $(5,10$, $25,50,100,200 \mu \mathrm{g} / \mathrm{ml}$ ) for $24 \mathrm{~h}$ and observed for cytotoxicity by MTT assay using ELISA reader. The cell survival plots were drawn between the \% viability, and different concentrations of these test derivatives have been given in Fig. 3. The $\mathrm{IC}_{50}$ values were calculated from these plots. The observations in statistical data of cell cytotoxicity study suggest that the different test derivatives have decreased the cell viability in a dose-dependent manner. The \% of cell viability decreased from 99 to $10 \%$ on treatment with the different concentrations of these test derivatives. At higher doses, the cell viability decreased up to $10-20 \%$ with almost all the test derivatives. Against HT-29 cells the selected test derivatives have shown good cytotoxic potential with the $\mathrm{IC}_{50}<100 \mu \mathrm{g} / \mathrm{ml}$ (Table 5). The derivatives NS-21 and NS-23 both found to have very good cytotoxic potential against HT-29 cells with $\mathrm{IC}_{50}=4-9 \mu \mathrm{g} / \mathrm{ml}$ as compared to the standard drug doxorubicin $\left(\mathrm{IC}_{50}=5 \mu \mathrm{g} / \mathrm{ml}\right)$. NS-2 and NS-8 derivatives have also shown good cytotoxic potential with $\mathrm{IC}_{50}$ of $19.26 \mu \mathrm{g} / \mathrm{ml}$ and $17.8 \mu \mathrm{g} / \mathrm{ml}$ respectively followed by derivatives NS-6, NS-11, and NS-15 which exhibited significant cytotoxicity with $\mathrm{IC}_{50}<50 \mu \mathrm{g} / \mathrm{ml}$. From the cytotoxicity study, the test derivative NS-2 (being the best antibacterial agent) and NS-21 (being the best cytotoxic agent having lowest $\mathrm{IC}_{50}$ ) were selected for the evaluation of apoptotic potential by flow cytometry.

\section{Morphological changes}

The HT-29 cells treated with different concentrations of the test derivatives were also observed under inverted phase microscope (Biolink) at $24 \mathrm{~h}$ for various morphological changes like the density of cells, the shape of the cells (HT 29 cells have the dual morphology of adherent as well as suspension nature), and any signs of shrinkage. In Fig. 4, it is evident that the test derivatives have reduced the number and clumping of cells. The higher concentrations of the test derivatives have significantly reduced the number of HT-29 cells.

\section{Apoptosis induction by test compounds}

The induction of apoptosis in HT-29 cells was studied by the Annexin-V (AV)/propidium iodide (PI) double staining assay using flow cytometry. This assay is based on the interaction of AV with phosphatidylserine (PS) (normally present in the inner membrane but translocated to the outer membrane during apoptosis) on the cell surface. The strong affinity of AV-FITC with PS due to loss of plasma membrane asymmetry leads to AV+/PI- staining in the early apoptotic cells. The intact cell membrane of the live cells is not permeable to AV and PI and hence represents AV-/PI- staining whereas $\mathrm{AV}+/ \mathrm{PI}+$ staining represents the late apoptotic cells. Necrotic cells are represented by $\mathrm{AV}-/$ PI+ staining on account of penetration of PI through the membranes and intercalation into the nucleic acid due to loss of the plasma and nuclear membrane integrity. The HT-29 cells were treated with the test derivatives and standard drug (doxorubicin) at their $\mathrm{IC}_{50}$ concentrations (NS-2: $\mathrm{IC}_{50}=19.6 \mu \mathrm{g} / \mathrm{ml}$, NS-21: $\mathrm{IC}_{50}=4.82 \mu \mathrm{g} / \mathrm{ml}$, Doxorubicin: $\mathrm{IC}_{50}=5.0 \mu \mathrm{g} / \mathrm{ml}$ ) for $24 \mathrm{~h}$ and then analyzed by flow cytometry [BD FACScalibur, Cell Quest Pro Software (Version: 6.0)]. Figures $5,6,7,8$, represents the cytometry results for the test derivatives vs untreated control and doxorubicin. Figure $5 \mathrm{a}-\mathrm{d}$ indicates the selection of the cells which are mainly single and segregated required for the cell cytometry. Figure $6 \mathrm{a}-\mathrm{d}$ represents the histogram of AV-FITC vs cell counts, detecting the number of AVFITC positive cells. Figure $7 \mathrm{a}$ reveals the untreated HT-29 cells representing the $98.23 \%$ population of the viable cells, $0.03 \%$ necrotic cells, $0.18 \%$ early apoptotic, and $1.55 \%$ late apoptotic/secondary necrotic cells. Figure $7 \mathrm{~b}$ corresponds to the doxorubicin-treated HT-29 cells with $21.06 \%$ population of viable cells, $10.95 \%$ necrotic cells, $4.67 \%$ of early apoptotic cells and the $63.33 \%$ of the late apoptotic cells. In case of NS-2 and NS-21 (Fig. 7c, d), the HT-29 cells population were; $9.78 \%$ and $37.75 \%$ viable population, $0.05 \%$ and $0.09 \%$ necrotic cells, $11.88 \%$ and $27.21 \%$ early apoptotic cells, and $78.29 \%$ and $34.95 \%$, late apoptotic cells respectively. These results indicate that the cells treated with test derivatives NS-2 and NS-21 have significantly undergone apoptosis after $24 \mathrm{~h}$ post-treatment compared to the untreated cells and doxorubicin-treated cells. The NS-2 has induced apoptosis in $>90 \%$ of the cells in the early and late apoptotic phase, whereas the NS-21 has shown comparable results (62\% of the cells in the early and late apoptotic phase) to that of the doxorubicin (68\% of apoptotic cells) (Fig. 8). Additionally, the treatment of cells with the NS-2 and NS-21 demonstrated no concurrent increase in the number of necrotic cells as in the case of doxorubicin which showed an increase in necrotic cells up to $10.89 \%$. Therefore, the NS-2 and NS-21 attest the antiproliferation mechanism in HT-29 cells through the induction of apoptosis. 


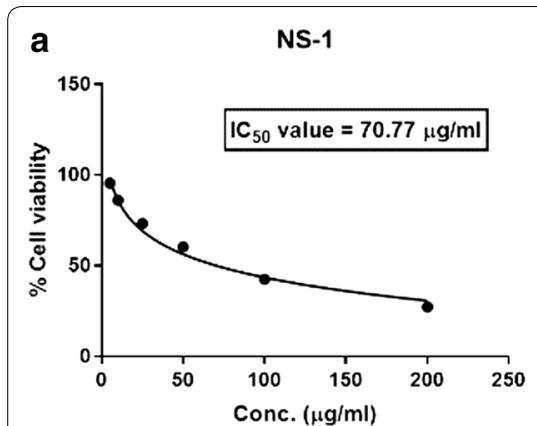

d

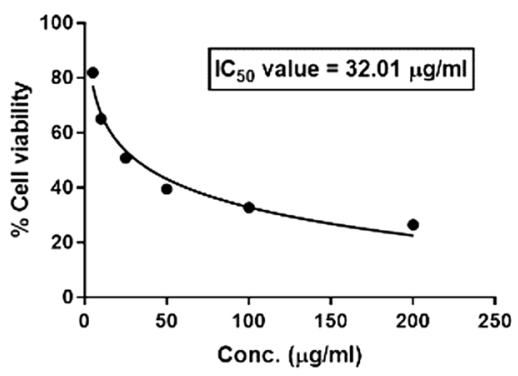

g

NS-12

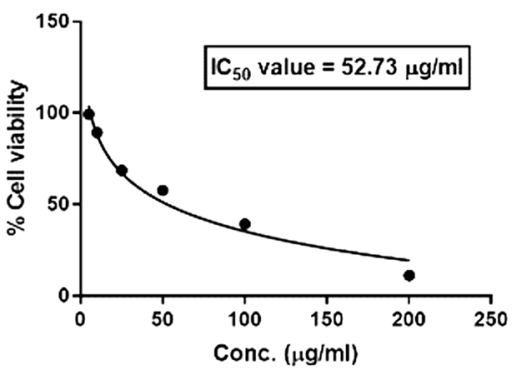

j

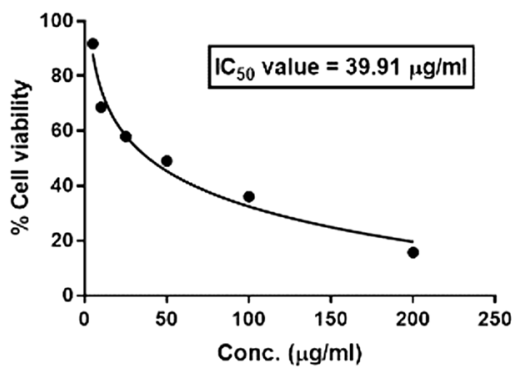

b

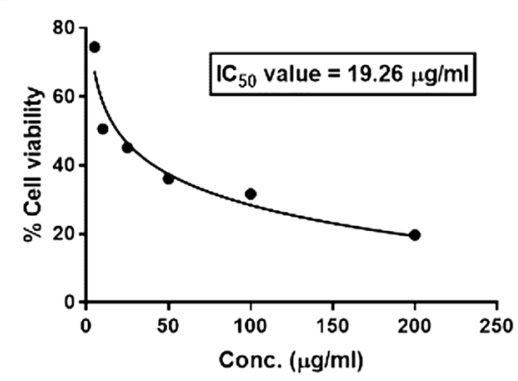

e

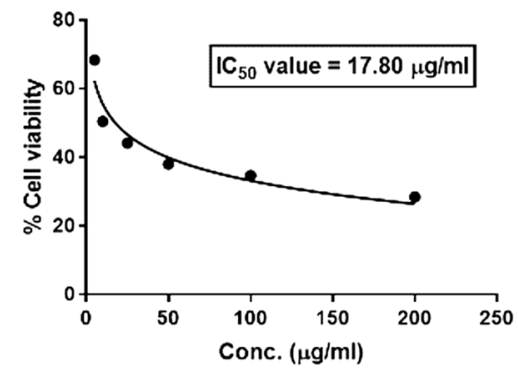

h

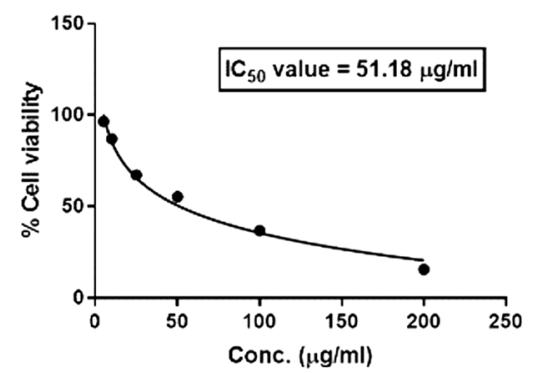

k

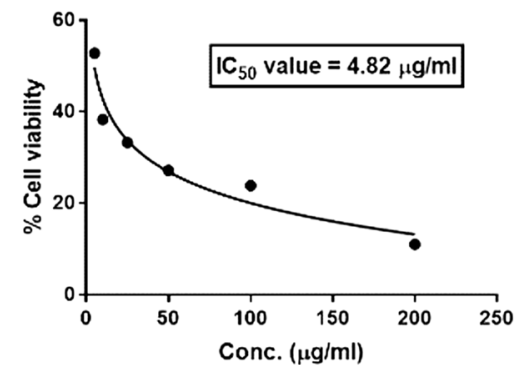

C NS-4

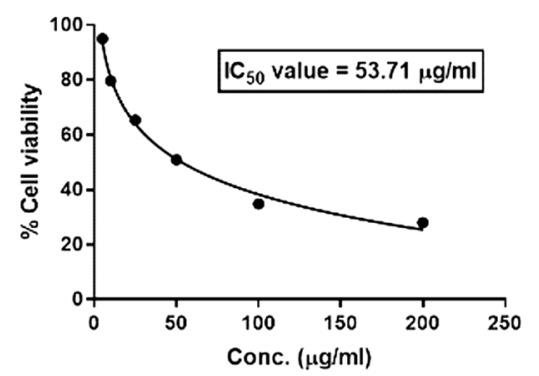

f

NS-11

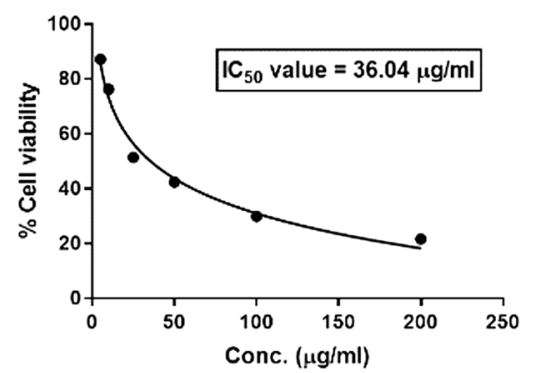

i

NS-14

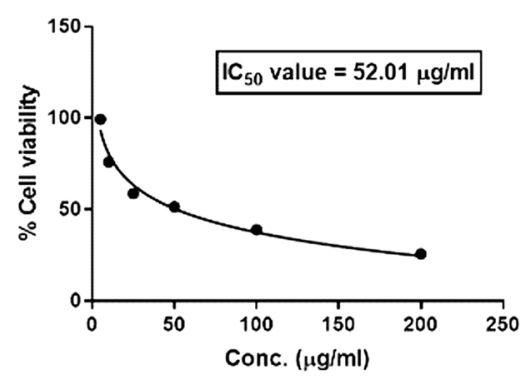

I

NS-23

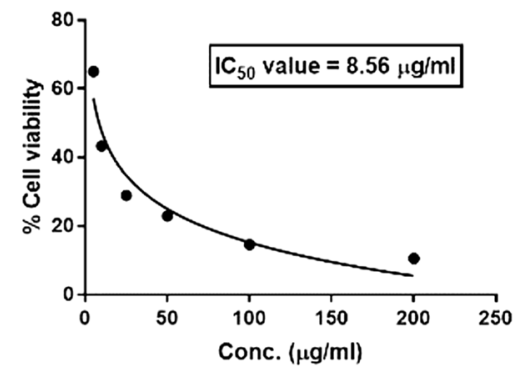

Fig. 3 Survival curve plots for $I C_{50}$ of synthesized naphthol based diazenyl Schiff bases: a NS-1; b NS-2; c NS-4; $\mathbf{d}$ NS-6; e NS-8; f NS-11; $\mathbf{g}$ NS-12; $\mathbf{h}$ NS-13; i NS-14; j NS-15; k NS-21; I NS-23

\section{S and G2/M phase arrest of the cell cycle}

To determine the possible effects on arresting the specific phase of cell growth, the HT-29 cells were treated with the $\mathrm{IC}_{50}$ concentrations of the NS-2, NS-21, and doxorubicin for $24 \mathrm{~h}$ and then stained with PI and observed for the count of cells in each phase of the cell cycle by flow cytometry. The results of the study have been presented in Figs. 9a-d and 10. Figure 9a represents the untreated cells with a population of $0.29 \%$ in the sub-G0/G1 phase, $69.98 \%$ in $\mathrm{G0} / \mathrm{G} 1$ phase, $15.83 \%$ in $\mathrm{S}$ phase, and $15.26 \%$ in G2/M phase of the cell cycle. The untreated cells or control presented very less number of the cells in the subG0/G1 phase a condition of a very sparse population of the apoptotic cells. On the contrary, doxorubicin treated 
Table 5 IC I0 $_{0}$ of synthesized naphthol based diazenyl Schiff bases against HT-29 cell line

\begin{tabular}{lll}
\hline S. No. & Sample code & $\mathbf{I C}_{\mathbf{5 0}}(\boldsymbol{\mu g} \mathbf{g} \mathbf{m})$ \\
\hline 1 & NS-1 & 70.77 \\
2 & NS-2 & 19.26 \\
3 & NS-4 & 53.71 \\
4 & NS-6 & 32.01 \\
5 & NS-8 & 17.8 \\
6 & NS-11 & 36.04 \\
7 & NS-12 & 52.73 \\
8 & NS-13 & 51.18 \\
9 & NS-14 & 52.01 \\
10 & NS-15 & 38.91 \\
11 & NS-21 & 4.82 \\
12 & NS-23 & 8.56 \\
13 & Doxorubicin & 5 \\
\hline
\end{tabular}

cells presented a population of $15.14 \%$ cells in the subG0/G1 phase, which constituted a large proportion of the apoptosis cells (Fig. 9b). The doxorubicin has arrested the cell cycle in G0/G1 phase, and the number of cells in this phase is $70.97 \%$ with a significant decrease in the proportion of cells in S (8.77\%) and the G2/M (5.21\%) phases as shown in Fig. 10. The test derivatives NS-2 and NS-21 presented the $28.29 \%$ and $5.16 \%$ of the cell population in the sub-G0/G1 phase respectively as indicated in Fig. 9c, d. The increased sub G0/G1 peak in the cell cycle for NS2 treated HT-29 cells demonstrate enhanced apoptosis in these cells. The derivative NS-2 also showed a dramatic decrease in the proportion of the G0/G1 phase cells (17.79\%) as compared to the control group cells (69.98\%) and arrested the cell growth in the S phase $(20.3 \%$ cells population) and G2/M phase (30.38\% cells population) of the cell cycle (Figs. 9c and 10). The derivative NS-21 have also followed the similar trend of arresting cells in the S phase (19.95\%) and G2/M phase (21.09\%) of the cell cycle. From the above results, it is clear that the derivative NS-2 has high ability to induce apoptosis in HT-29 cells in comparison to the doxorubicin. Both these test derivatives have arrested the cell cycle in the $\mathrm{S}$ and G2/M phases of the cell cycle, which is crucial for the cell division and proliferation.

\section{Experimental}

The chemicals and other reagents for synthesis were procured from Merck Chemicals (India) and used without further purification. The nutrient media for the antimicrobial evaluation and other chemicals required for cytotoxicity study were purchased from Hi-Media Laboratories (India). The microbial strains were acquired from Institute of Microbial Technology and Genebank (IMTECH), Chandigarh. The FTIR spectrophotometer Bruker 12060280 was used for recording the IR spectra. Electronic absorption spectra were taken in the methanolic solution of diazenyl Schiff bases on double beam UV-visible spectrophotometer (Shimadzu). The purity of compounds was checked by NMR spectroscopy $\left({ }^{1} \mathrm{H}\right.$ $\mathrm{NMR}$ and $\left.{ }^{13} \mathrm{C} \mathrm{NMR}\right)$, carried out in deuterated $\mathrm{CDCl}_{3}$ and DMSO solvents on Bruker Avance II 300 NMR spectrometer at a frequency of $300 \mathrm{MHz}$ and $75 \mathrm{MHz}$ and Bruker Avance II 400 NMR spectrometer at a frequency of $400 \mathrm{MHz}$ and $100 \mathrm{MHz}$ respectively. The elemental analysis was performed on CHNN/CHNS/O analyzer (Flash $\backslash$ EA1112Nseries, Thermofinnigan, Italy). The structures of the synthesized derivatives were confirmed by

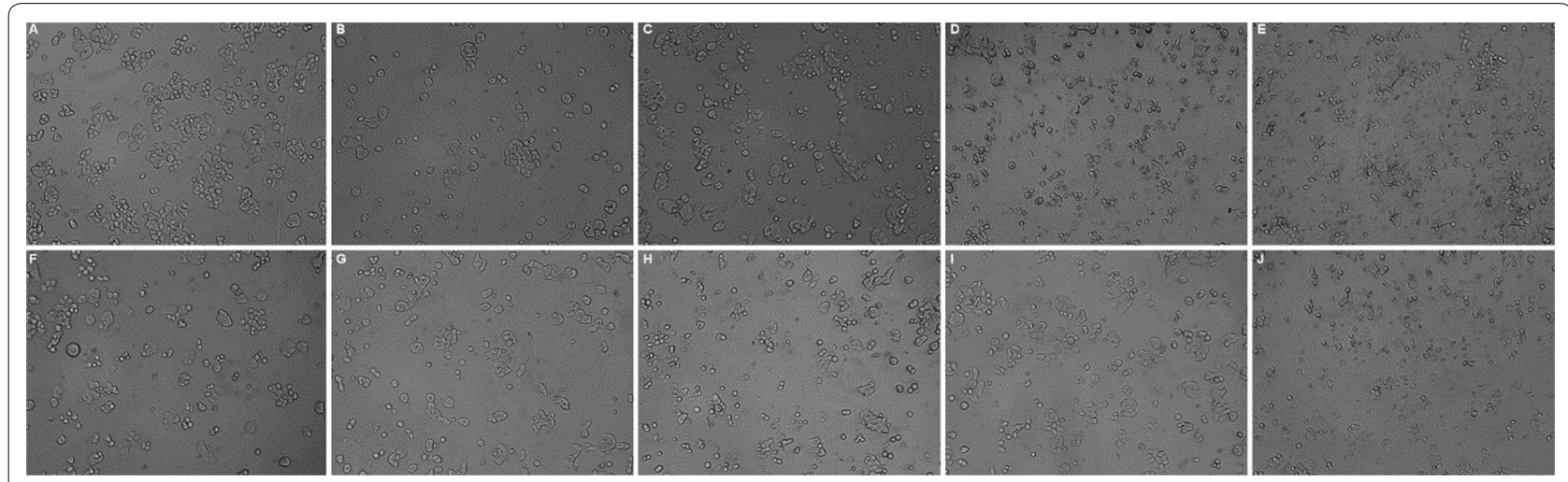

Fig. 4 Morphological characterization of HT-29 cell after treatment with control, standard and different naphthol diazenyl scaffold Schiff bases recorded with the inverted phase microscope (Biolink) after $24 \mathrm{~h}$ of the treatment. $\mathbf{a}$ Untreated cells; $\mathbf{b} \mathrm{HT}-29$ cells treated with the standard at $5 \mu \mathrm{g} / \mathrm{ml} ; \mathbf{c}$ NS-2 treated cells at $25 \mu \mathrm{g} / \mathrm{ml} ; \mathbf{d}$ NS-4 treated cells at $50 \mu \mathrm{g} / \mathrm{ml} \mathbf{d}$ NS-6 treated cells at $25 \mu \mathrm{g} / \mathrm{ml} ; \mathbf{e}$ NS-8 treated cells at $25 \mu \mathrm{g} / \mathrm{ml} ; \mathbf{f}$ NS-12 treated cells at $50 \mathrm{\mu g} / \mathrm{ml} ; \mathbf{g ~ N S}-13$ treated cells at $50 \mu \mathrm{g} / \mathrm{ml} ; \mathbf{h}$ NS-14 treated cells at $50 \mu \mathrm{g} / \mathrm{ml} ; \mathbf{i}$ NS-21 treated cells at $5 \mu \mathrm{g} / \mathrm{ml} ; \mathbf{j}$ NS-23 treated cells at $10 \mu \mathrm{g} / \mathrm{ml}$ 

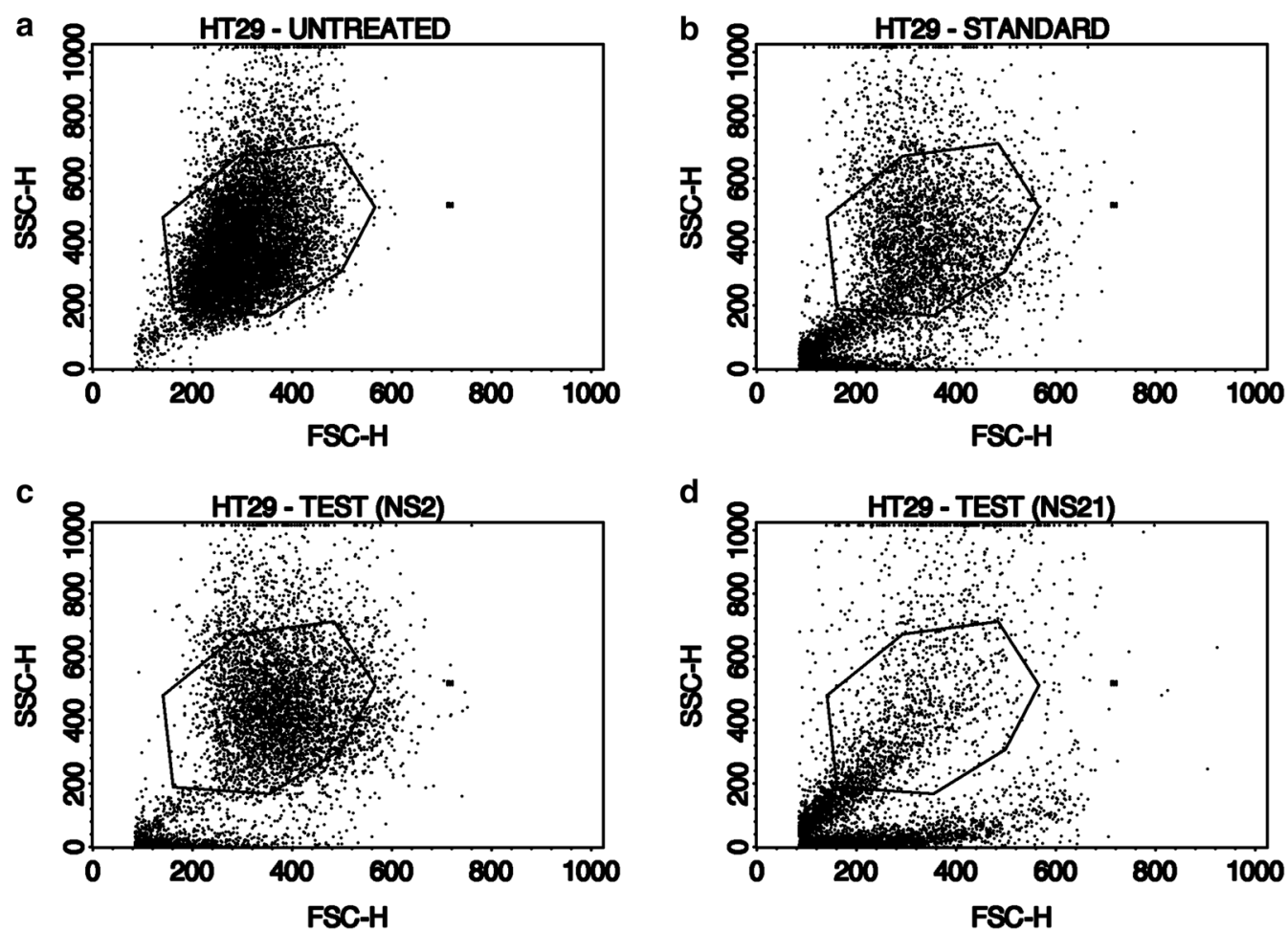

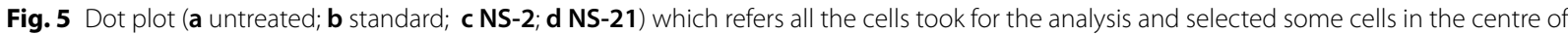
this plot called as gated cells (selected region) R1-Region 1 since those cells are single cells and cells of our interest. Above the gated region cells are clumped cells or may be double or triple clump of cells and below the gated region cells are debris or dead cells. Cells based on the cells size and granularity will appear in the dot plot where FSC_Forward scattering light refers granularity and shape of cells and SSC-Side Scattering light refers size of the cells
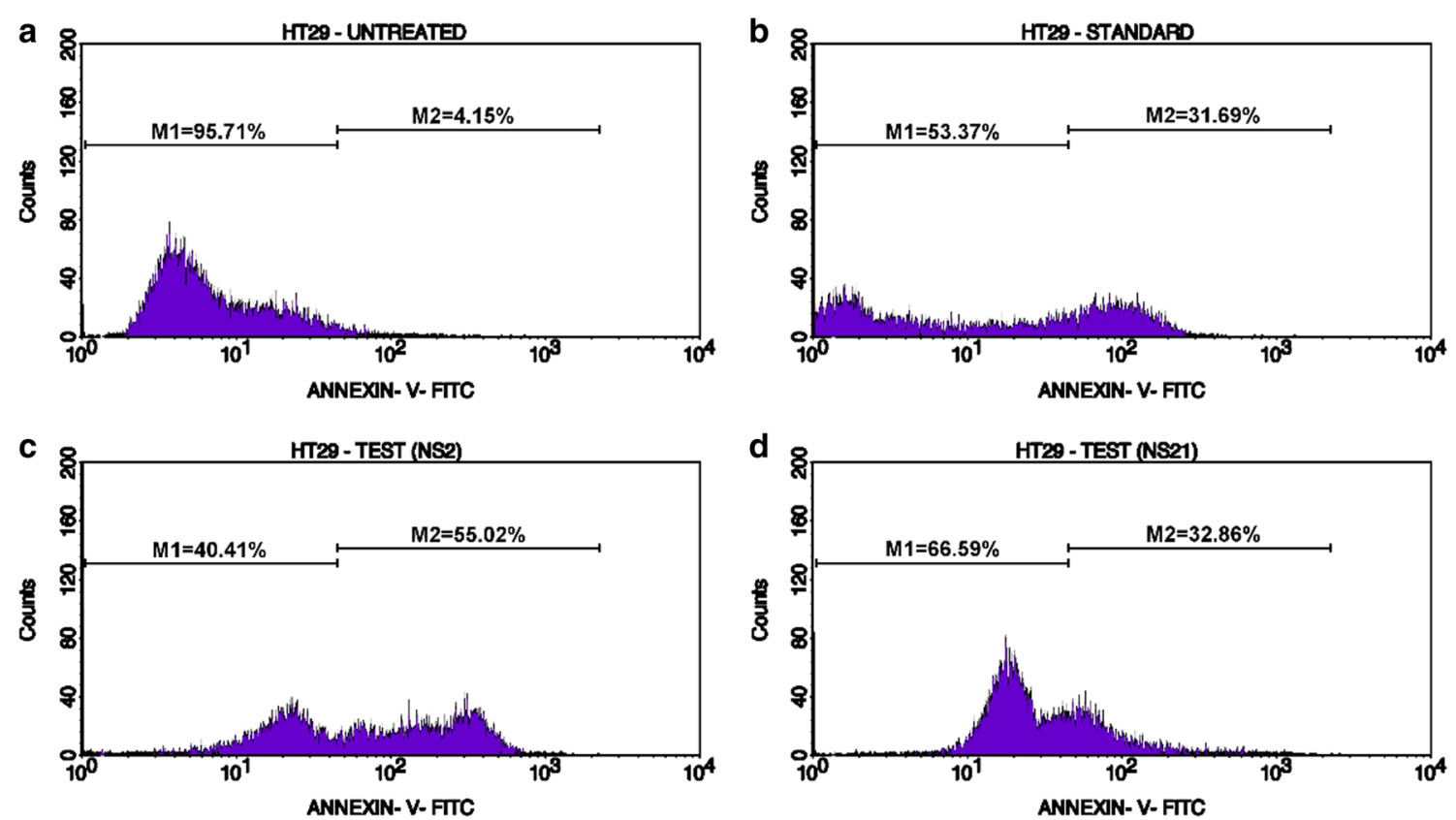

Fig. 6 Histogram presenting the no. of viable and apoptotic cells in $\mathbf{a}$ untreated; $\mathbf{b}$ standard; c NS-2; d NS-21 on HT-29 cells. The M1 populations are the viable cells that are low in mean Annexin V-FITC fluorescence intensity while M2 populations are the apoptotic cells that have taken up the Annexin V-FITC and are high in mean Annexin V-FITC fluorescence intensity 

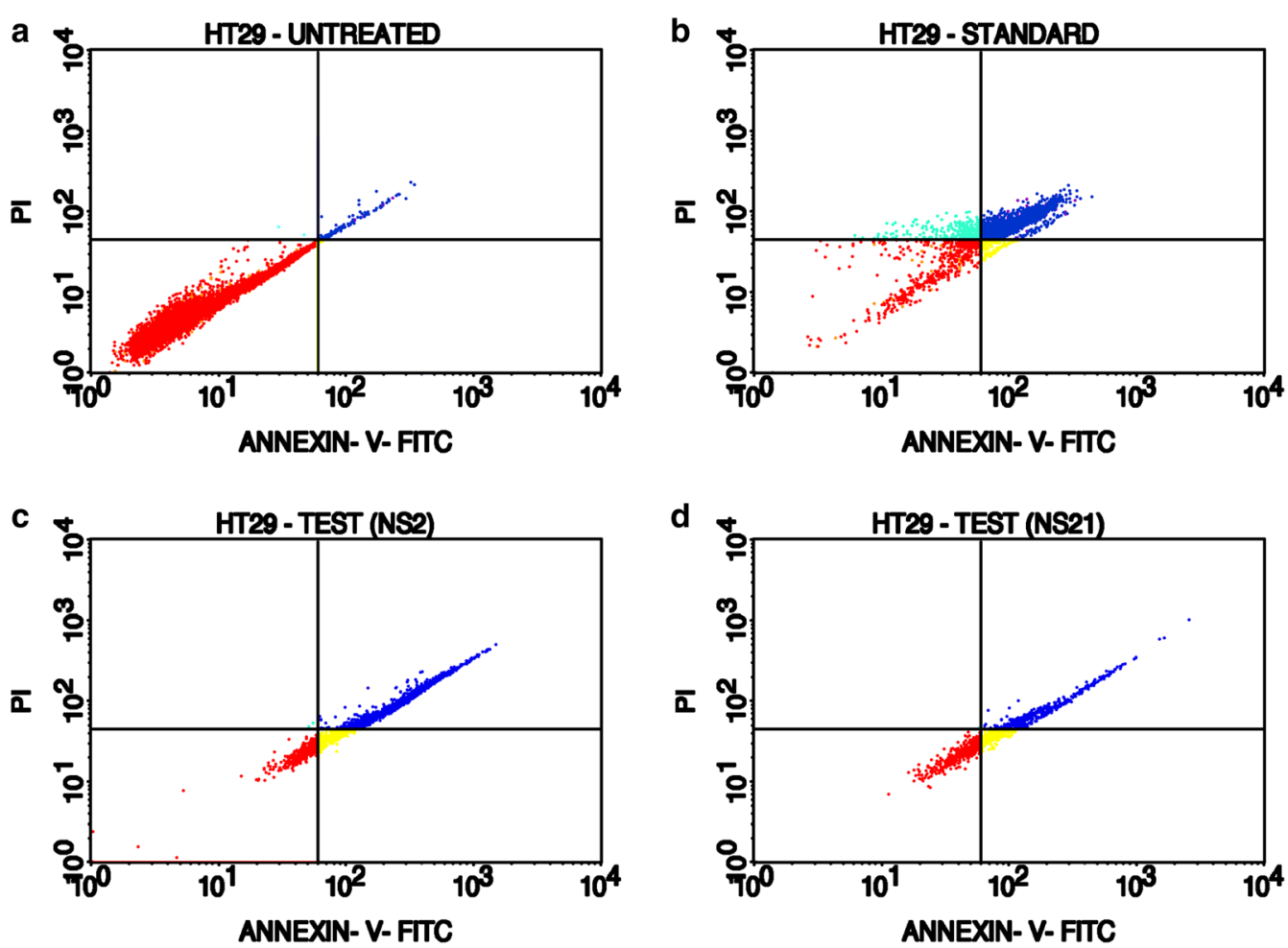

Fig. 7 Annexin V-PI expression study of untreated, standard and test compounds (NS-2 and NS-21) on HT-29 cells using BD FACScalibur, Cell Quest Pro Software (Version: 6.0). Quadrants showing the expression \% of various type of cells: a lower left (LL) quadrant represent the \% of viable cells, b lower right (LR) quadrant represent the \% of early apoptotic cells, c upper left (UL) quadrant represent the \% of necrotic cells, d upper right (UR) quadrant represent the \% of late apoptotic cells against the Annexin V-FITC and propidium iodide Stain. Where Annexin V-FITC-primary marker, $\mathrm{Pl}$ - propidium iodide (secondary fluorescence marker)

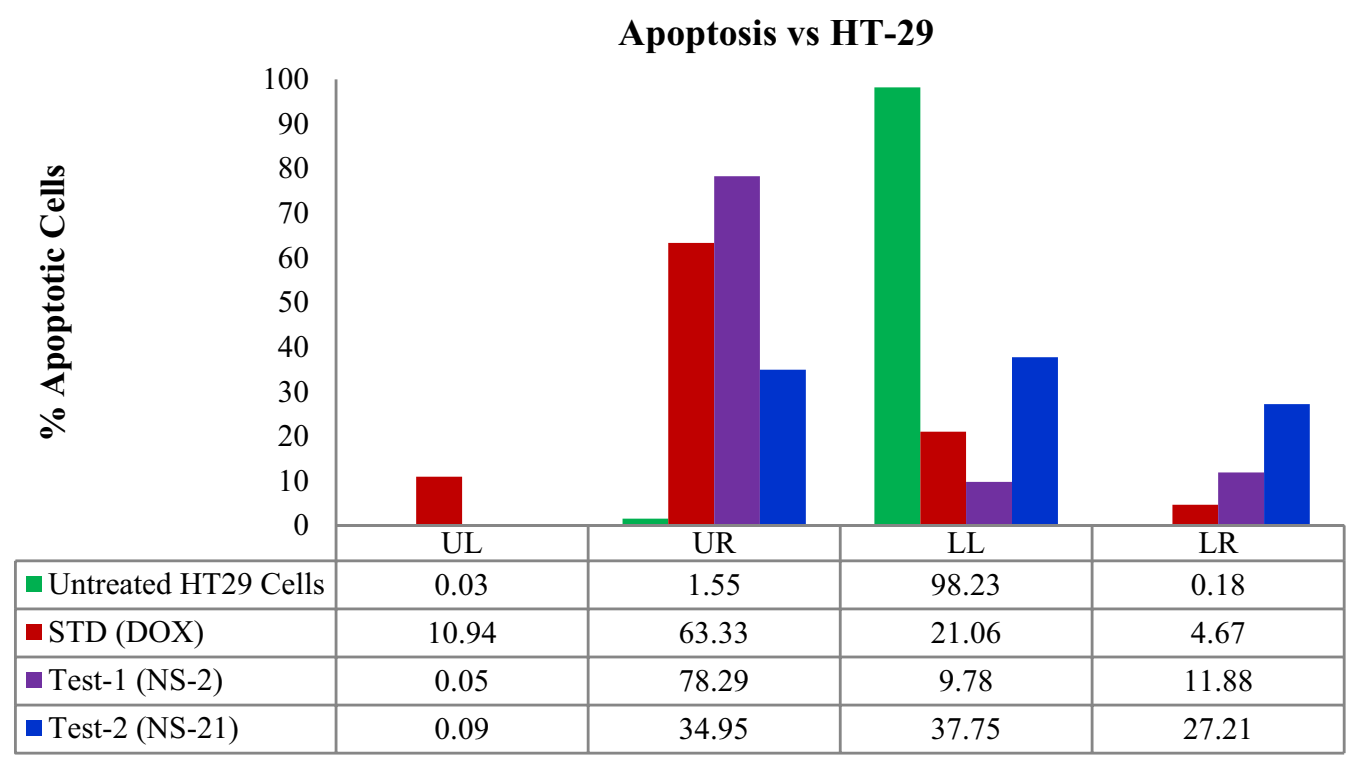

Fig. 8 Comparison of control, standard and test compounds (NS-2 and NS-21) showing the \% of viable, early apoptotic, late apoptotic and necrotic cells against the Annexin V-FITC and Propidium iodide stain assay 

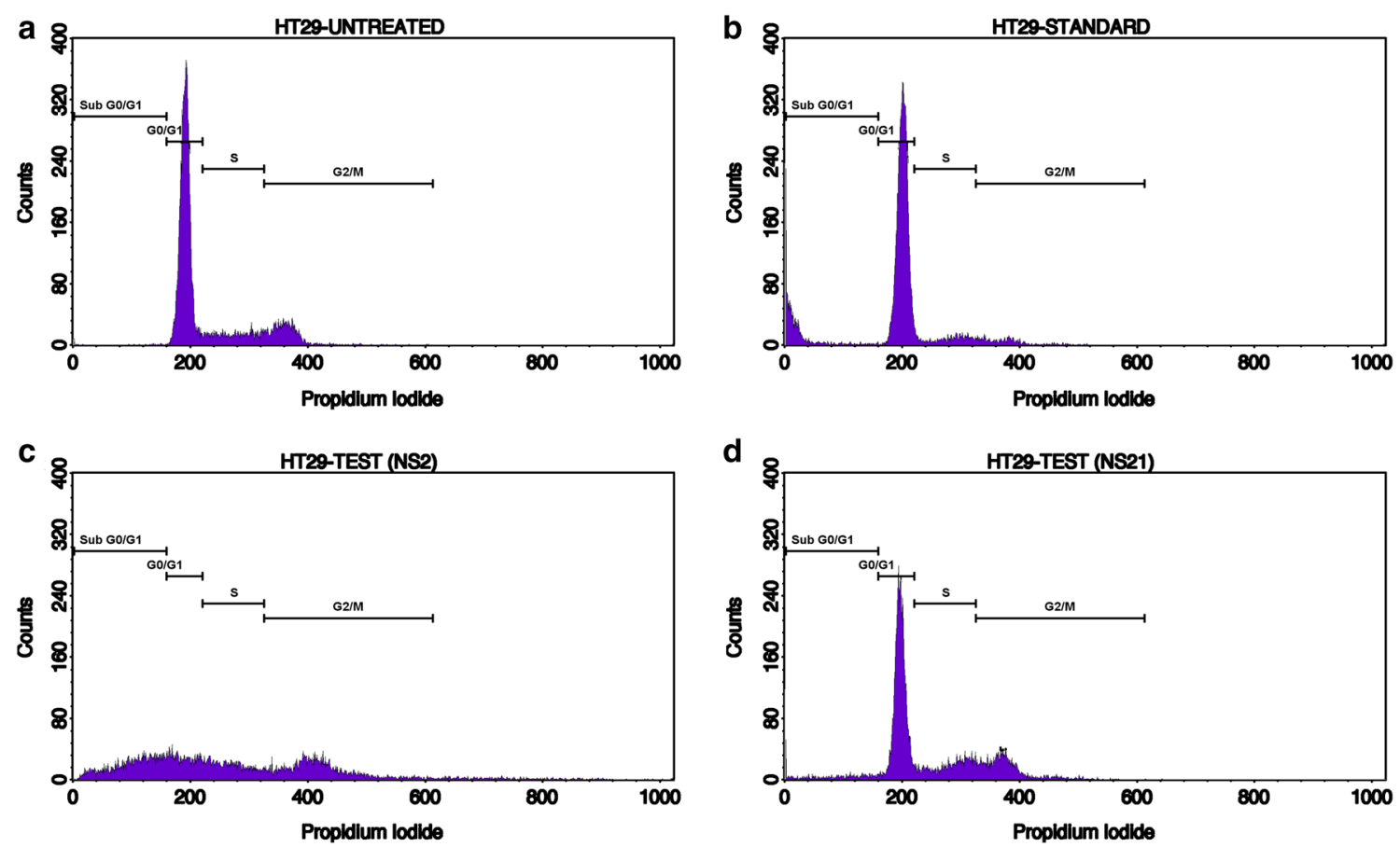

Fig. 9 Histograms showing the cell cycle distribution of untreated (a), standrad drug (doxorubicin-5 $\mu \mathrm{g}$ ) (b), and test compound-1 (NS-2) (c) and test compound-2 (NS-21) (d) against HT29 cells using BD FACScalibur. PI histogram of the gated cell singlets distinguishes cells at the Sub G0/ G1, G0/G1, S, and G2/M cycle phases. Gating of cell cycle phases is approximate and can be refined using software (Cell Quest Software, Version 6.0) analysis. For each analysis 10,000 singlet cells were gated into Sub GO/G1, GO/G1, S and G2/M phases for the analysis for all samples including controls as indicated in the histograms

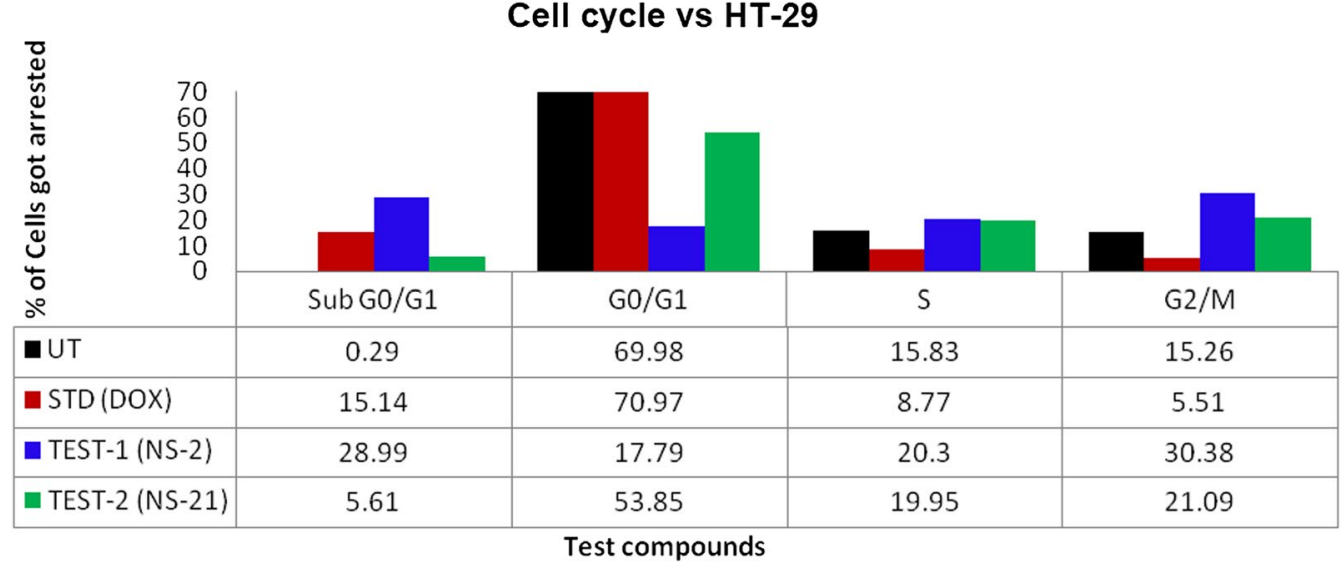

Fig. 10 Comparison of control, standard and test compounds (NS-2 and NS-21) showing the \% of cell arrested in different phases of the cell cycle

mass spectra, taken on the Advion expression CMS, USA mass spectrometer with APCI mode as the ion source.

\section{General procedure for the synthesis of diazenyl Schiff bases (NS1-NS23)}

Hydrochloric acid (8 $\mathrm{ml}, 33 \%)$ was added dropwise to the well-stirred suspension of mono- or di-substituted aniline derivative $(0.01 \mathrm{~mol})$ in $\mathrm{H}_{2} \mathrm{O}(15 \mathrm{ml})$ followed by cooling to $0-5{ }^{\circ} \mathrm{C}$ on an ice bath. Afterward, a cold solution of sodium nitrite $(0.01 \mathrm{~mol})$ in $\mathrm{H}_{2} \mathrm{O}(7 \mathrm{ml})$ was added with continuous stirring throughout 5-10 min. The stirring was further continued for $30 \mathrm{~min}$ at $0-5{ }^{\circ} \mathrm{C}$. The excess of nitrous acid was neutralized by the addition of urea and tested by potassium iodide paper. The clear diazo solution formed was used for successive coupling reaction and added dropwise to the 
well-stirred solution of 2-hydroxy-1-naphthaldehyde $(0.01 \mathrm{~mol})$ in ethanol, over a period of $10-15 \mathrm{~min}$ at $0-5{ }^{\circ} \mathrm{C}$. The $\mathrm{pH}$ of the solution was maintained at 8.5 by simultaneous addition of $\mathrm{Na}_{2} \mathrm{CO}_{3}$ solution $(10 \%$ $\mathrm{w} / \mathrm{v})$ with continuous stirring, maintaining the temperature below $5{ }^{\circ} \mathrm{C}$. The solution was acidified with $\mathrm{HCl}(\mathrm{pH}=1.0)$ at the completion of the reaction to precipitate the azo dyes (ND1-ND5) which were filtered, washed with $\mathrm{NaCl}$ solution ( $5 \% \mathrm{w} / \mathrm{v})$, and air dried. The dyes (ND1-ND5) were further used for the synthesis of Schiff bases (NS1-NS23) by reaction of diazenyl dyes (5 mmol) with various aliphatic, aromatic or heteroaromatic amines $(5 \mathrm{mmol})$ in ethanol/DMSO solvents and traces (5-7 drops) of acetic acid. The refluxing of the reaction mixture was continued for 7-8 h until the reaction completion was confirmed by TLC. The reaction volume was concentrated to half and kept at $10-15{ }^{\circ} \mathrm{C}$ for the precipitation of Schiff bases [37]. The precipitated Schiff bases were collected by filtration, washed with ice-cold ethanol and dried in air. The synthesized derivatives were purified by column chromatography and recrystallization techniques.

\section{Analytical data}

4-((4-Formyl-3-hydroxynaphthalen-2-yl)diazenyl)benzoic acid (ND-1) MF: $\mathrm{C}_{18} \mathrm{H}_{12} \mathrm{~N}_{2} \mathrm{O}_{4}$; Orange color; Yield: 80\%; $\mathrm{R}_{\mathrm{f}}=0.31$ (hexane/ethyl acetate 5:2); mp: $123-125{ }^{\circ} \mathrm{C}$; IR $\left(\right.$ ATR, $\mathrm{cm}^{-1}$ ) $v_{\max }: 3398.03,3302.80,3246.47,3055.65$, 2979.11, 2822.97, 1691.70, 1628.16, 1512.03, 1460.32, $1396.83,1306.56,1242.68,1159.08,1074.38,953.15$, 858.47, 792.13, 744.46, 653.00; ${ }^{1} \mathrm{H}$ NMR $(400 \mathrm{MHz}$, DMSO-d $\left.{ }_{6}\right) \delta: 14.19(\mathrm{~s}, 1 \mathrm{H}), 12.93(\mathrm{~s}, 1 \mathrm{H}), 10.78(\mathrm{~s}, 1 \mathrm{H})$, $8.97(\mathrm{~d}, J=5.6 \mathrm{~Hz}, 1 \mathrm{H}), 7.95-8.07(\mathrm{~m}, 2 \mathrm{H}), 7.47-7.97(\mathrm{~m}$, $4 \mathrm{H}), 7.06-7.39(\mathrm{~m}, 2 \mathrm{H}) ;{ }^{13} \mathrm{C}$ NMR (100 MHz, DMSO-d $\left.\mathrm{d}_{6}\right)$ $\delta: 193.34,171.56,164.39,157.31,142.20,140.01,138.89$, 132.18, 129.77, 128.05, 124.71, 122.64, 119.21, 112.92.

3-((2,5-Dichlorophenyl)diazenyl)-2-hydroxy-1-naphthaldehyde (ND-2) MF: $\quad \mathrm{C}_{17} \mathrm{H}_{10} \mathrm{Cl}_{2} \mathrm{~N}_{2} \mathrm{O}_{2} ;$ Orange color, Yield: $85 \% ; \mathrm{R}_{\mathrm{f}}=0.34$ (hexane/ethyl acetate 5:2); mp: $58-60{ }^{\circ} \mathrm{C}$; IR (ATR, $\left.\mathrm{cm}^{-1}\right) v_{\max }: 3365.00,3280.23$, 3206.33, 3021.98, 1630.08, 1553.22, 1460.76, 1397.38, $1305.59,1241.64,1160.01,1086.20,1024.67,967.95$, 857.79, 789.12, 742.15, 648.73; ${ }^{1} \mathrm{H}$ NMR $(400 \mathrm{MHz}$, DMSO- $\left.\mathrm{d}_{6}\right) \delta: 12.01(\mathrm{~s}, 1 \mathrm{H}), 10.84(\mathrm{~s}, 1 \mathrm{H}), 8.94(\mathrm{~s}, 1 \mathrm{H})$, $8.14(\mathrm{~s}, 1 \mathrm{H}), 7.89(\mathrm{~d}, J=8.0 \mathrm{~Hz}, 1 \mathrm{H}), 7.62(\mathrm{t}, J=8.0 \mathrm{~Hz}$, $1 \mathrm{H}), 7.42(\mathrm{t}, J=8.0 \mathrm{~Hz}, 1 \mathrm{H}), 7.29(\mathrm{~d}, J=8.0 \mathrm{~Hz}, 1 \mathrm{H}), 7.02-$ $7.24(\mathrm{~m}, 2 \mathrm{H}) ;{ }^{13} \mathrm{C}$ NMR (100 MHz, DMSO-d $\left.{ }_{6}\right) \delta: 193.20$, $164.45,156.14,141.16,140.01,137.23,134.26,132.13$, $129.64,128.32,124.45,123.14,118.23,113.65$.
3-((2,4-Dimethylphenyl)diazenyl)-2-hydroxy-1-naphthaldehyde (ND-3) MF: $\mathrm{C}_{19} \mathrm{H}_{16} \mathrm{~N}_{2} \mathrm{O}_{2}$; Orange color; Yield: 69\%; $\mathrm{R}_{\mathrm{f}}=0.39$ (hexane/ethyl acetate 5:2); mp: $102-104{ }^{\circ} \mathrm{C}$. IR (ATR, $\left.\mathrm{cm}^{-1}\right) v_{\max }: 3489.40,3055.30,1734.34,1631.55$, $1596.00,1471.20,1433.55,1391.80,1348.90,1241.81$, 1144.27, 795.81, 736.98, 655.26; ${ }^{1} \mathrm{H}$ NMR $(400 \mathrm{MHz}$, DMSO-d $\left.{ }_{6}\right) \delta: 13.84(\mathrm{~s}, 1 \mathrm{H}), 10.84(\mathrm{~s}, 1 \mathrm{H}), 8.94(\mathrm{~s}, 1 \mathrm{H})$, $8.15(\mathrm{~s}, 1 \mathrm{H}), 7.86(\mathrm{~d}, J=8.0 \mathrm{~Hz}, 1 \mathrm{H}), 7.63(\mathrm{t}, J=8.0 \mathrm{~Hz}$, $1 \mathrm{H}), 7.40(\mathrm{t}, J=8.0 \mathrm{~Hz}, 1 \mathrm{H}), 7.02-7.38(\mathrm{~m}, 3 \mathrm{H}), 2.35(\mathrm{~s}$, $3 \mathrm{H}), 2.38(\mathrm{~s}, 3 \mathrm{H}) ;{ }^{13} \mathrm{C}$ NMR $\left(100 \mathrm{MHz}, \mathrm{DMSO}-\mathrm{d}_{6}\right) \delta$ : $194.34,165.46,156.22,141.16,140.01,139.13,135.26$, $133.23,132.13,129.64,128.16,124.45,123.45,118.23$, $21.23,18.17$.

3-((4-Chloro-2-nitrophenyl)diazenyl)-2-hydroxy-1-naphthaldehyde (ND-4) MF: $\mathrm{C}_{17} \mathrm{H}_{10} \mathrm{ClN}_{3} \mathrm{O}_{4}$; Orange color; Yield: $72 \%$; mp: $88-90{ }^{\circ} \mathrm{C} ; \mathrm{R}_{\mathrm{f}}=0.37$ (hexane/ethyl acetate 5:2); IR (ATR, $\mathrm{cm}^{-1}$ ) $v_{\max }: 3409.00,3067.45,2915.67$, $1738.45,1635.15,1590.59,1464.22,1398.95,1311.40$, 1246.47, 1163.39, 1079.34, 857.43, 793.83, 744.81, 529.16, 468.11; ${ }^{1} \mathrm{H}$ NMR (400 MHz, DMSO-d 6 ) $\delta: 14.84(\mathrm{~s}, 1 \mathrm{H})$, $10.81(\mathrm{~s}, 1 \mathrm{H}), 8.54(\mathrm{~s}, 1 \mathrm{H}), 8.05(\mathrm{~s}, 1 \mathrm{H}), 7.89(\mathrm{~d}, J=8.0 \mathrm{~Hz}$, $1 \mathrm{H}), 7.62(\mathrm{t}, J=8.0 \mathrm{~Hz}, 1 \mathrm{H}), 7.40(\mathrm{t}, J=8.0 \mathrm{~Hz}, 1 \mathrm{H}), 7.12-$ $7.38(\mathrm{~m}, 3 \mathrm{H}) ;{ }^{13} \mathrm{C}$ NMR $\left(100 \mathrm{MHz}\right.$, DMSO-d $\left.\mathrm{d}_{6}\right) \delta: 193.01$, 168.12 , 163.20, 154.16, 142.11, 140.02, 135.81, 132.23, $130.29,129.65,128.11,127.56,126.34,123.12,116.71$.

3-((2-Chloro-4-nitrophenyl)diazenyl)-2-hydroxy-1-naphthaldehyde (ND-5) MF: $\mathrm{C}_{17} \mathrm{H}_{10} \mathrm{ClN}_{3} \mathrm{O}_{4}$; Orange color; Yield: 76\%; mp: $95-97^{\circ} \mathrm{C} ; \mathrm{R}_{\mathrm{f}}=0.32$ (hexane/ethyl acetate 5:2); IR (ATR, $\mathrm{cm}^{-1}$ ) $v_{\max }: 3409.00,3067.45,2915.67$, $1738.45,1635.15,1590.59,1464.22,1398.95,1311.40$, 1246.47, 1163.39, 1079.34, 857.43, 793.83, 744.81, 529.16, 468.11; ${ }^{1} \mathrm{H}$ NMR (400 MHz, DMSO-d $\left.{ }_{6}\right) \delta: 14.62$ (s, 1H), $10.65(\mathrm{~s}, 1 \mathrm{H}), 8.57(\mathrm{~m}, 1 \mathrm{H}), 8.14(\mathrm{~s}, 1 \mathrm{H}), 7.99(\mathrm{~d}$, $J=7.6 \mathrm{~Hz}, 1 \mathrm{H}), 7.76(\mathrm{~d}, J=7.6 \mathrm{~Hz}, 1 \mathrm{H}), 7.64-7.69(\mathrm{~m}$, $1 \mathrm{H}), 7.51(\mathrm{t}, J=8.0 \mathrm{~Hz}, 1 \mathrm{H}), 7.37(\mathrm{~d}, J=8.4 \mathrm{~Hz}, 1 \mathrm{H}), 6.82$ $(\mathrm{d}, J=9.2 \mathrm{~Hz}, 1 \mathrm{H}) ;{ }^{13} \mathrm{C}$ NMR $\left(100 \mathrm{MHz}\right.$, DMSO- $\left.\mathrm{d}_{6}\right) \delta$ : $193.21,167.39,161.10,155.21,143.25,140.01,134.08$, $132.00,130.26,129.75,127.72,127.27,125.56,122.74$, 116.71 .

\section{2-Hydroxy-4-((2-hydroxy3-(4-carboxyphenyldiaze-} nyl)naphthalen-1-yl)methyleneamino) benzoic acid (NS-1) Maroon color, Yield: 61\%; mp: $273-275{ }^{\circ} \mathrm{C}$; $\mathrm{R}_{\mathrm{f}}=0.72$ (hexane/ethyl acetate 3:2); IR (ATR, $\mathrm{cm}^{-1}$ ) $v_{\max }$ : $3682.17,3555.32,3497.91,3384.31,3324.28,1781.17$, $1744.65,1619.56,1524.89,1425.25,1330.14,1277.93$, 1201.80, 1132.58, 1024.97, 947.13, 725.95, 627.24; ${ }^{1} \mathrm{H}$ NMR (400 MHz, DMSO-d $\left.\mathrm{d}_{6}\right) \delta: 15.78(\mathrm{~s}, 1 \mathrm{H}), 12.03-12.24$ $(\mathrm{m}, 2 \mathrm{H}), 10.82(\mathrm{~s}, 1 \mathrm{H}), 9.71(\mathrm{~s}, 1 \mathrm{H}), 8.92(\mathrm{~d}, J=4.8 \mathrm{~Hz}$, $1 \mathrm{H}), 8.54(\mathrm{~d}, J=8.4 \mathrm{~Hz}, 1 \mathrm{H}), 7.82-8.12(\mathrm{~m}, 5 \mathrm{H}), 7.56(\mathrm{t}$, $J=7.2 \mathrm{~Hz}, 1 \mathrm{H}), 7.37(\mathrm{t}, J=7.2 \mathrm{~Hz}, 1 \mathrm{H}), 7.08-7.10(\mathrm{~m}$, 
$2 \mathrm{H}) ;{ }^{13} \mathrm{C}$ NMR (100 MHz, DMSO-d $\left.{ }_{6}\right) \delta: 170.56,168.66$, $165.54,160.40,154.69,142.31,139.29,137.19,136.30$, $133.36,129.40,128.38,127.37,123.91,123.06,121.55$, $121.09,118.74,116.35,108.32$; APCI-MS $\mathrm{m} / \mathrm{z}$ found for $\mathrm{C}_{25} \mathrm{H}_{17} \mathrm{~N}_{3} \mathrm{O}_{6}: 455\left(\mathrm{M}^{+}\right)$; Anal. calcd for $\mathrm{C}_{25} \mathrm{H}_{17} \mathrm{~N}_{3} \mathrm{O}_{6}$ : C 65.93, H 3.76 N 9.23, O 21.08 found: C 65.92, H 3.75, N 9.24, O 21.07 .

4-((4-((Furan-2-ylmethylimino)methyl)-3-hydroxynaphthalen-2-yl)diazenyl)benzoic acid (NS-2) Maroon color, Yield: 66\%; mp: $283-285{ }^{\circ} \mathrm{C} ; \mathrm{R}_{\mathrm{f}}=0.52$ (hexane/ ethyl acetate 5:2); IR (ATR, $\mathrm{cm}^{-1}$ ) $v_{\max }: 3400.17,1732.62$, $1702.98,1636.96,1547.93,1506.09,1465.93,1424.45$, $1395.38,1317.10,1260.22,1215.21,1161.60,1038.68$, 1009.89, 967.34, 902.84, 856.15, 822.68, 748.38, 673.59, 654.15, 635.64; ${ }^{1} \mathrm{H}$ NMR $\left(300 \mathrm{MHz}, \mathrm{CDCl}_{3}\right) \delta: 14.20(\mathrm{~s}$, $1 \mathrm{H}), 12.99(\mathrm{~s}, 1 \mathrm{H}), 8.92(\mathrm{~s}, 1 \mathrm{H}), 7.91(\mathrm{~d}, J=8.1 \mathrm{~Hz}, 2 \mathrm{H})$, 7.59-7.90 (m, 2H), 7.37-7.56 (m, 5H), $7.27(\mathrm{~d}, J=6.6 \mathrm{~Hz}$, $1 \mathrm{H}), 6.98(\mathrm{~d}, J=6.6 \mathrm{~Hz}, 1 \mathrm{H}), 6.37(\mathrm{~d}, J=6.6 \mathrm{~Hz}, 1 \mathrm{H}), 4.79$ (s, 2H); ${ }^{13} \mathrm{C}$ NMR (75 MHz, $\left.\mathrm{CDCl}_{3}\right) \delta: 170.19,165.15$, $161.10,156.13,151.34,142.29,141.27,134.16,133.13$, $130.80,129.47,128.95,128.46,126.98,126.09,125.83$, 123.28, 121.48, 116.27, 108.41, 56.41; APCI-MS m/z found for $\mathrm{C}_{23} \mathrm{H}_{17} \mathrm{~N}_{3} \mathrm{O}_{4}$ : $399.12\left(\mathrm{M}^{+}\right)$; Anal. calcd for $\mathrm{C}_{23} \mathrm{H}_{17} \mathrm{~N}_{3} \mathrm{O}_{4}$ : C 69.17, H 4.29, N 10.52, O 16.02 found: $\mathrm{C}$ 69.19, H 4.26, N 10.49, O 16.05.

4-((4-((3-(Ethoxycarbonyl)-4,5,6,7-tetrahydrobenzo[b] thiophen-2-ylimino)methyl)-3-hydroxynaphthalen-2-yl) diazenyl)benzoic acid (NS-4) Maroon crystals; Yield: 71\%; mp: $130-132{ }^{\circ} \mathrm{C} ; \mathrm{R}_{\mathrm{f}}=0.57$ (hexane/ethyl acetate 7:3); IR (ATR, $\mathrm{cm}^{-1}$ ) $v_{\max }: 3430.05,3368.85,3255.36,3070.81$, 2886.96, 1816.95, 1673.57, 1599.99, 1545.80, 1454.97, 1356.37, 1281.25, 1225.93, 1119.51, 1069.00, 933.52, 893.52, 814.12, 725.42, 624.59; ${ }^{1} \mathrm{H}$ NMR $(400 \mathrm{MHz}$, DMSO-d $\left.\mathrm{d}_{6}\right) \delta: 14.49(\mathrm{~s}, 1 \mathrm{H}), 12.99(\mathrm{~s}, 1 \mathrm{H}), 9.46(\mathrm{~s}, 1 \mathrm{H}), 8.45$ (d, $J=8.8 \mathrm{~Hz}, 1 \mathrm{H}), 8.02-8.07(\mathrm{~m}, 2 \mathrm{H}), 7.87-7.98(\mathrm{~m}, 2 \mathrm{H})$, 7.59-7.62 (m, 1H), 7.41-7.50 (m, 1H), $7.19(\mathrm{~d}, J=8.8 \mathrm{~Hz}$, $1 \mathrm{H}), 6.80(\mathrm{~d}, J=8.8 \mathrm{~Hz}, 1 \mathrm{H}), 4.32(\mathrm{q}, J=7.2 \mathrm{~Hz}, 2 \mathrm{H})$, 2.73-2.75 (m, 4H), 1.79-1.80 (m, 4H), $1.35(\mathrm{t}, J=7.2 \mathrm{~Hz}$, $3 \mathrm{H}) ;{ }^{13} \mathrm{C}$ NMR $\left(75 \mathrm{MHz}, \mathrm{CDCl}_{3}\right) \delta: 172.03,165.30$, $163.53,153.75,153.17,138.21,135.90,132.67,130.80$, $129.31,127.94,127.77,123.71,123.24,120.67,119.43$, 109.66, 60.77, 26.33, 25.56, 22.89, 22.54, 14.45; APCI-MS $\mathrm{m} / \mathrm{z}$ found for $\mathrm{C}_{29} \mathrm{H}_{25} \mathrm{~N}_{3} \mathrm{O}_{5} \mathrm{~S}: 527.29\left(\mathrm{M}^{+}\right)$; Anal. calcd for $\mathrm{C}_{29} \mathrm{H}_{25} \mathrm{~N}_{3} \mathrm{O}_{5} \mathrm{~S}$ : C 66.02, H 4.78, N 7.96, O 15.16, S 6.08 found C 66.04, H 4.76, N 7.93, O 15.14 .

1-((4-Chloro-2-nitrophenylimino)methyl)-3-((2,5-dichlorophenyl)diazenyl)naphthalen-2-ol (NS-5) Orange color, Yield: 67\%; mp: $163-165{ }^{\circ} \mathrm{C} ; \mathrm{R}_{\mathrm{f}}=0.46$ (hexane/ ethyl acetate 5:2); IR (ATR, $\mathrm{cm}^{-1}$ ) $v_{\max }: 3327.59,3123.45$, 3036.46, 1705.79, 1636.95, 1554.55, 1505.69, 1460.28,
1407.17, 1347.62, 1251.66, 1191.63, 1122.96, 1072.17, 992.62, 919.62, 830.94, 801.99, 743.56, 681.44, 648.12, 628.84; ${ }^{1} \mathrm{H}$ NMR (400 MHz, DMSO-d $\left.{ }_{6}\right) \delta: 14.82(\mathrm{~s}, 1 \mathrm{H})$, $9.81(\mathrm{~s}, 1 \mathrm{H}), 8.54(\mathrm{~s}, 1 \mathrm{H}), 8.14-8.35(\mathrm{~m}, 2 \mathrm{H}), 7.86-7.99$ (m, 2H), 7.43-7.64 (m, 3H), 7.02-7.40 (m, 3H); ${ }^{13} \mathrm{C}$ NMR (100 MHz, DMSO-d d $\left._{6}\right) \delta: 166.19,156.19,148.38,133.66$, $133.59,129.58,129.53,129.49,129.40,129.19,129.11$, 128.47, 127.31, 123.10, 124. 64, 122.89, 119.89, 109.71; APCI-MS $\mathrm{m} / \mathrm{z}$ found for $\mathrm{C}_{23} \mathrm{H}_{13} \mathrm{Cl}_{3} \mathrm{~N}_{4} \mathrm{O}_{3}: 499.73\left(\mathrm{M}^{+}\right)$; Anal. calcd for $\mathrm{C}_{23} \mathrm{H}_{13} \mathrm{Cl}_{3} \mathrm{~N}_{4} \mathrm{O}_{3}$ : C 55.28, $\mathrm{H}$ 2.62, Cl 21.28, N 11.21, O 9.60 found C 55.29, H 2.65, N 11.17, O 9.58.

Ethyl 2-((2-hydroxy 3-(2,5-dichlorophenyldiazenyl)naphthalen-1-yl)methyleneamino)-4,5,6,7-tetrahydrobenzo [b]thiophene-3-carboxylate (NS-6) Maroon crystals; Yield: 68\%; $\mathrm{R}_{\mathrm{f}}=0.57$ (hexane/ethyl acetate 7:2); mp: 124$126{ }^{\circ} \mathrm{C}$; IR (ATR, $\mathrm{cm}^{-1}$ ) $v_{\max }: 3568.00,3094.03,3040.81$, $2974.81,2911.20,2366.67,1700.69,1606.35,1475.69$, 1371.47, 1297.35, 1196.50, 997.64, 870.26, 794.90; ${ }^{1} \mathrm{H}$ NMR (300 MHz, $\left.\mathrm{CDCl}_{3}\right) \delta: 14.83(\mathrm{~s}, 1 \mathrm{H}), 9.29(\mathrm{~s}, 1 \mathrm{H})$, $8.11(\mathrm{~d}, J=11.2 \mathrm{~Hz}, 1 \mathrm{H}), 7.71-7.83(\mathrm{~m}, 2 \mathrm{H}), 7.52-7.57$ (m, 1H), 7.33-7.39 (m, 1H), 7.15-7.27 (m, 3H), $4.44(\mathrm{q}$, $J=9.6 \mathrm{~Hz}, 2 \mathrm{H}), 2.74-2.82(\mathrm{~m}, 4 \mathrm{H}), 1.44-1.84(\mathrm{~m}, 4 \mathrm{H})$, $1.43(\mathrm{t}, J=9.6 \mathrm{~Hz}, 3 \mathrm{H}) ;{ }^{13} \mathrm{C}$ NMR $\left(75 \mathrm{MHz}, \mathrm{CDCl}_{3}\right) \delta$ : $168.30,166.54,165.28,163.52,156.52,156.21,153.19$, $138.89,138.77,135.86,135.74,133.82,132.64,132.31$, $130.95,130.78,129.29,128.99,127.92,127.73,126.72$, 123. $68,122.44,120.66,119.42,112.66,110.63,63.79$, 26.34, 25.91, 25.56, 22.88, 22.54, 17.50, 14.48; APCI-MS $\mathrm{m} / \mathrm{z}$ found for $\mathrm{C}_{28} \mathrm{H}_{23} \mathrm{Cl}_{2} \mathrm{~N}_{3} \mathrm{O}_{3} \mathrm{~S}$ : $551.08\left(\mathrm{M}^{+}\right)$; Anal. calcd for $\mathrm{C}_{28} \mathrm{H}_{23} \mathrm{Cl}_{2} \mathrm{~N}_{3} \mathrm{O}_{3} \mathrm{~S}: \mathrm{C}$ 60.87, $\mathrm{H} 4.20 \mathrm{Cl} 12.83, \mathrm{~N}$ 7.61, O 8.69 S 5.80 found C 60.85, H 4.19 N 7.63, O 8.68.

1-((2,5-Dichlorophenylimino)methyl)-3-((2,4-dimethylphenyl)diazenyl)naphthalen-2-ol (NS-7) Orange color, Yield: 63\%; $\mathrm{R}_{\mathrm{f}}=0.52$ (hexane/ethyl acetate 3:2); mp: $136-138{ }^{\circ} \mathrm{C}$; IR (ATR, $\mathrm{cm}^{-1}$ ) $v_{\max }: 3375.92,3151.83$, $3088.46,2943.78,2873.15,1719.05,1635.79,1544.30$, $1463.04,1400.54,130.27,1245.55,1177.83,1131.88$, 1074.45, 996.33, 940.63, 895.69, 754.43, 665.50; ${ }^{1} \mathrm{H}$ NMR $\left(400 \mathrm{MHz}, \mathrm{DMSO}-\mathrm{d}_{6}\right) \delta: 15.53(\mathrm{~s}, 1 \mathrm{H}), 9.83(\mathrm{~s}, 1 \mathrm{H})$, $8.64(\mathrm{~s}, 1 \mathrm{H}), 8.34(\mathrm{~d}, J=4.2 \mathrm{~Hz}, 1 \mathrm{H}), 8.02(\mathrm{~d}, J=9.2 \mathrm{~Hz}$, $1 \mathrm{H}), 7.85(\mathrm{~d}, J=8 \mathrm{~Hz}, 1 \mathrm{H}), 7.38-7.67(\mathrm{~m}, 6 \mathrm{H}), 7.11(\mathrm{~d}$, $J=9.2 \mathrm{~Hz}, 1 \mathrm{H}), 2.49(\mathrm{~s}, 3 \mathrm{H}), 2.39(\mathrm{~s}, 3 \mathrm{H}) ;{ }^{13} \mathrm{C} \mathrm{NMR}$ (100 MHz, DMSO- $\mathrm{d}_{6}$ ) $\delta: 168.49,159.07,143.82,137.79$, $133.46,133.39,131.60,129.50,128.68,127.66,127.57$, $126.43,124.43,121.53,121.43,120.33,109.87,25.69$, 15.31; APCI-MS m/z found for $\mathrm{C}_{28} \mathrm{H}_{23} \mathrm{Cl}_{2} \mathrm{~N}_{3} \mathrm{O}_{3} \mathrm{~S}: 551.08$ $\left(\mathrm{M}^{+}\right)$; Anal. calcd for $\mathrm{C}_{25} \mathrm{H}_{19} \mathrm{Cl}_{2} \mathrm{~N}_{3} \mathrm{O}: \mathrm{C} 66.97, \mathrm{H} 4.27 \mathrm{Cl}$ 15.82, N 9.37, O 3.57 S 5.80 found C 60.85, H 4.19 N 7.63, O 8.68. 
((E)-Ethyl 2-((2-hydroxy 3-(2,5 dichlorophenyldiazenyl) naphthalen-1-yl)methyleneamino)-4-(2-thienyl) thiophene-3-carboxylate (NS-8) Red Fluffy; Yield: 56\%; mp: $150-152{ }^{\circ} \mathrm{C} ; \mathrm{R}_{\mathrm{f}}=0.64$ (hexane/ethyl acetate 4:1); IR $\left(\right.$ ATR, $\left.\mathrm{cm}^{-1}\right) v_{\max }: 3411.22,3362.17,3297.94,3146.85$, 3024.30, 2927.92, 2875.89, 1813.05, 1728.86, 1651.67, $1570.54,1455.02,1403.86,1353.24,1302.51,1118.90$, 1071.95, 963.19, 823.50, 751.85, 668.34, 623.73; ${ }^{1} \mathrm{H}$ NMR $\left(400 \mathrm{MHz}, \mathrm{DMSO}-\mathrm{d}_{6}\right) \delta: 14.58(\mathrm{~s}, 1 \mathrm{H}), 9.45(\mathrm{~s}, 1 \mathrm{H}), 8.44$ $(\mathrm{d}, J=8 \mathrm{~Hz}, 1 \mathrm{H}), 8.16(\mathrm{~s}, 1 \mathrm{H}), 8.03(\mathrm{~d}, J=7.6 \mathrm{~Hz}, 1 \mathrm{H}), 7.89$ $(\mathrm{d}, J=2.4 \mathrm{~Hz}, 1 \mathrm{H}), 7.58-7.70(\mathrm{~m}, 5 \mathrm{H}), 7.43(\mathrm{t}, J=7.2 \mathrm{~Hz}$, $1 \mathrm{H}), 7.19(\mathrm{~d}, J=9.2 \mathrm{~Hz}, 1 \mathrm{H}), 6.82(\mathrm{~d}, J=9.2 \mathrm{~Hz}, 1 \mathrm{H}), 4.32$ (q, $J=7.2 \mathrm{~Hz}, 2 \mathrm{H}), 1.35(\mathrm{t}, J=7.2 \mathrm{~Hz}, 3 \mathrm{H}) ;{ }^{13} \mathrm{C}$ NMR $\left(100 \mathrm{MHz}, \mathrm{DMSO}-\mathrm{d}_{6}\right) \delta: 167.66,161.40,156.69,154.69$, $144.15,141.26,139.16,137.19,136.30,133.36,129.40$, $128.36,127.37,123.91,123.06,121.55,121.09,120.74$, 118.35, 116.22, 109.22, 63.14, 17.65; APCI-MS m/z found for $\mathrm{C}_{28} \mathrm{H}_{19} \mathrm{Cl}_{2} \mathrm{~N}_{3} \mathrm{O}_{3} \mathrm{~S}_{2}$ : $579.08\left(\mathrm{M}^{+}\right)$; Anal. calcd for $\mathrm{C}_{28} \mathrm{H}_{19} \mathrm{Cl}_{2} \mathrm{~N}_{3} \mathrm{O}_{3} \mathrm{~S}_{2}$ : C 57.93, H 3.30, Cl 12.21, N 7.24, O 8.27, S 11.05 found C 57.95, H 3.29, N 7.23, O 8.28.

1-((2-chloro-4-nitrophenylimino)methyl)-3-((2,4-dichlorophenyl)diazenyl)naphthalen-2-ol: $\quad$ (NS-9) Orange color, Yield: 75\%; mp: $145-148{ }^{\circ} \mathrm{C} ; \mathrm{R}_{\mathrm{f}}=0.56$ (hexane/ethyl acetate 3:2); IR: 3397.56, 2888.01, 2706.56, $2624.92,1674.85,1561.71,1499.61,1332.79,1291.62$, 1123.56, 1071.35, 951.05, 888.01, 826.51, 742.29; ${ }^{1} \mathrm{H}$ NMR (400 MHz, DMSO-d $\left.)_{6}\right) \delta: 16.07(\mathrm{~s}, 1 \mathrm{H}), 9.80(\mathrm{~s}$, $1 \mathrm{H}), 8.57(\mathrm{~d}, J=8.0 \mathrm{~Hz}, 1 \mathrm{H}), 8.48(\mathrm{~s}, 1 \mathrm{H}), 8.34(\mathrm{~s}, 1 \mathrm{H})$, $8.16(\mathrm{~d}, J=2.4 \mathrm{~Hz}, 1 \mathrm{H}), 7.99-8.01(\mathrm{~m}, 1 \mathrm{H}), 7.77(\mathrm{~d}$, $J=8.0 \mathrm{~Hz}, 1 \mathrm{H}), 7.63-7.71(\mathrm{~m}, 1 \mathrm{H}), 7.52(\mathrm{t}, J=7.6 \mathrm{~Hz}$, $1 \mathrm{H}), 7.37-7.40(\mathrm{~m}, 1 \mathrm{H}), 7.10(\mathrm{~s}, 1 \mathrm{H}), 6.84(\mathrm{~d}, J=10 \mathrm{~Hz}$, $1 \mathrm{H}) ;{ }^{13} \mathrm{C}$ NMR (100 MHz, DMSO- $\mathrm{d}_{6}$ ): 166.71, 163.56, $157.72,153.25$, 151.87, 145.69, 143.29, 141.45, 138.56, $136.34,132.02,130.29,129.76,127.28,126.25,125.59$, 125.43, 124.31, 122.77, 116.72, 109.78; APCI-MS m/z found for $\mathrm{C}_{23} \mathrm{H}_{13} \mathrm{Cl}_{3} \mathrm{~N}_{4} \mathrm{O}_{3}$ : $499\left(\mathrm{M}^{+}\right)$; Anal. calcd for $\mathrm{C}_{23} \mathrm{H}_{13} \mathrm{Cl}_{3} \mathrm{~N}_{4} \mathrm{O}_{3}$ : C 55.28., $\mathrm{H}$ 2.62, $\mathrm{Cl} 21.28, \mathrm{~N} 11.21, \mathrm{O}$ 9.60 found C 55.31, H 2.59, N 11.17, O 9.57.

((E)-Ethyl 2-((2-hydroxy 3-(2,5 dichlorophenyldiazenyl) naphthalen-1-yl)methyleneamino)-4-(2, 4 dihydroxyphenylthienyl) thiophene-3-carboxylate (NS-10) Maroon color, Yield: $63 \% ; \mathrm{R}_{\mathrm{f}}=0.74$ (hexane/ethyl acetate $3: 2$ ); mp: $130-133{ }^{\circ} \mathrm{C}$; IR (ATR, $\mathrm{cm}^{-1}$ ) $v_{\max }: 3426.91,3310.91$, 3171.12, 3069.50, 1828.70, 1747.69, 1680.17, 1563.58, $1515.21,1454.32,1379.35,1283.47,1116.01,989.49$, 861.16, 747.55, 688.55, 633.85; ${ }^{1} \mathrm{H}$ NMR $(400 \mathrm{MHz}$, DMSO- $\left.\mathrm{d}_{6}\right) \delta: 16.08(\mathrm{~s}, 1 \mathrm{H}), 12.11-12.34(\mathrm{~m}, 2 \mathrm{H}), 9.75(\mathrm{~s}$, $1 \mathrm{H}), 8.58(\mathrm{~d}, J=8 \mathrm{~Hz}, 1 \mathrm{H}), 8.22(\mathrm{~d}, J=7.6 \mathrm{~Hz}, 1 \mathrm{H}), 8.16(\mathrm{~d}$, $J=2.4 \mathrm{~Hz}, 1 \mathrm{H}), 8.18(\mathrm{~d}, J=2.4 \mathrm{~Hz}, 1 \mathrm{H}), 7.79(\mathrm{~d}, J=7.6 \mathrm{~Hz}$, $1 \mathrm{H}), 7.53-7.77(\mathrm{~m}, 2 \mathrm{H}), 7.50-7.52(\mathrm{~m}, 2 \mathrm{H}), 7.16-7.39$ $(\mathrm{m}, 2 \mathrm{H}), 6.82(\mathrm{~d}, J=7.6 \mathrm{~Hz}, 1 \mathrm{H}), 4.32(\mathrm{q}, J=7.2 \mathrm{~Hz}, 2 \mathrm{H})$, $1.35(\mathrm{t}, J=7.2 \mathrm{~Hz}, 3 \mathrm{H}) ;{ }^{13} \mathrm{C}$ NMR $(100 \mathrm{MHz}, \mathrm{DMSO}-$ $\left.\mathrm{d}_{6}\right) \delta: 168.56,163.96,159.46 .157 .20,155.25,150.88$, $148.27,144.62,141.54,133.71,131.56,131.11,130.47$, $129.45,129.28,127.80,127.65,127.45,124.98,116.03$, 114.27, 108.81, 102.09, 61.06, 14.43; APCI-MS m/z found for $\mathrm{C}_{30} \mathrm{H}_{21} \mathrm{Cl}_{2} \mathrm{~N}_{3} \mathrm{O}_{5} \mathrm{~S}$ : $605\left(\mathrm{M}^{+}\right)$; Anal. calcd for $\mathrm{C}_{30} \mathrm{H}_{21} \mathrm{Cl}_{2} \mathrm{~N}_{3} \mathrm{O}_{5} \mathrm{~S}$ : C 59.41, H 3.49; Cl 11.69, N 6.93, O 13.19, S 5.29 found C.59.43, H 3.48, N 6.94, O 13.178.

(E)-3-((2,5-dichlorophenyl) diazenyl)-1-((furan-2-ylmethylimino)methyl)naphthalen-2-ol (NS-11) Maroon color, Yield: $64 \% ; \mathrm{R}_{\mathrm{f}}=0.44$ (hexane/ethyl acetate $3: 2$ ); mp: $68-70{ }^{\circ} \mathrm{C}$; IR (ATR, $\mathrm{cm}^{-1}$ ) $v_{\max }: 3367.69,3254.68$, $3135.41,2993.51,2888.91,2353.45,1664.24,1591.44$, $1484.94,1386.94,1322.25,1202.01,1082.30,1003.24$, 916.27, 813.44, 731.84, 663.67; ${ }^{1} \mathrm{HNMR}(400 \mathrm{MHz}$, DMSO-d 6 ) $\delta: 14.02(\mathrm{~s}, 1 \mathrm{H}), 8.94(\mathrm{~d}, J=8.4 \mathrm{~Hz}, 1 \mathrm{H}), 8.51$ $(\mathrm{s}, 1 \mathrm{H}), 8.14(\mathrm{~d}, J=8.4 \mathrm{~Hz}, 1 \mathrm{H}), 7.89(\mathrm{~d}, J=8.0 \mathrm{~Hz}, 1 \mathrm{H})$, $7.62(\mathrm{t}, J=8.0 \mathrm{~Hz}, 1 \mathrm{H}), 7.43(\mathrm{t}, J=8.0 \mathrm{~Hz}, 1 \mathrm{H}), 7.38-7.40$ (m, 1H), $7.43(\mathrm{t}, J=8.0 \mathrm{~Hz}, 1 \mathrm{H}), 7.38-7.40(\mathrm{~m}, 1 \mathrm{H}), 7.23$ $(\mathrm{d}, J=9.2 \mathrm{~Hz}, 1 \mathrm{H}), 6.53(\mathrm{~s}, 1 \mathrm{H}), 6.45(\mathrm{~d}, J=1.6 \mathrm{~Hz}, 1 \mathrm{H})$, $4.76(\mathrm{~s}, 2 \mathrm{H}) ;{ }^{13} \mathrm{C}$ NMR (100 MHz, DMSO-d 6 ): 166.14, $160.23,155.34,145.27,142.29,141.27,134.17,133.13$, $130.80,129.47,128.95,128.46,126.98,126.10,125.83$, $122.28,116.75,112.75,109.53,54.51$; APCI-MS m/z found for $\mathrm{C}_{22} \mathrm{H}_{15} \mathrm{Cl}_{2} \mathrm{~N}_{3} \mathrm{O}_{2}: 423\left(\mathrm{M}^{+}\right)$; Anal. calcd for $\mathrm{C}_{22} \mathrm{H}_{15} \mathrm{Cl}_{2} \mathrm{~N}_{3} \mathrm{O}_{2}$ : C 62.28., $\mathrm{H}$ 3.56; $\mathrm{Cl} 16.71, \mathrm{~N}$ 9.90, O 7.54 found C 62.26, H 3.52 N 9.89, O 7.56.

(E)-3-((2,5-dichlorophenyl) diazenyl)-1-((4-methylpyridin-2-ylimino) methyl)naphthalen-2-ol) (NS-12) Red color; Yield: $67 \% ; \mathrm{R}_{\mathrm{f}}=0.52$ (hexane/ethyl acetate 3:2); mp: $70-72{ }^{\circ} \mathrm{C}$; IR (ATR, $\mathrm{cm}^{-1}$ ) $v_{\max }: 3429.20,3310.25$, 3063.91, 1681.87, 1611.58, 1546.17, 1463.44, 1328.96, 1255.15, 1074.37, 876.25, 802.90, 729.57; ${ }^{1} \mathrm{H} \quad \mathrm{NMR}$ (400 MHz, DMSO-d $\left.\mathrm{d}_{6}\right): 16.08(\mathrm{~s}, 1 \mathrm{H}), 9.82(\mathrm{~s}, 1 \mathrm{H}), 8.93(\mathrm{~d}$, $J=8.4 \mathrm{~Hz}, 1 \mathrm{H}), 8.22(\mathrm{~d}, J=7.6 \mathrm{~Hz}, 1 \mathrm{H}), 7.79(\mathrm{~d}, J=7.6 \mathrm{~Hz}$, $1 \mathrm{H}), 7.53-7.77(\mathrm{~m}, 5 \mathrm{H}), 7.50-7.52(\mathrm{~m}, 2 \mathrm{H}), 7.36-7.39$ $(\mathrm{m}, 2 \mathrm{H}), 6.82(\mathrm{~d}, J=2.4 \mathrm{~Hz}, 1 \mathrm{H}), 2.28(\mathrm{~s}, 3 \mathrm{H}) ;{ }^{13} \mathrm{C}$ NMR $\left(100 \mathrm{MHz}\right.$, DMSO-d $\mathrm{d}_{6}$ ): 166.34, 164.15, 160.82, 157.92, $154.92,143.89,141.42,139.12,135.61,134.27,132.64$, $131.29,130.11,130.00,128.10,124.62,122.72,121.02$, 120.63, 115.87, 109.86, 27.06; APCI-MS m/z found for $\mathrm{C}_{23} \mathrm{H}_{16} \mathrm{Cl}_{2} \mathrm{~N}_{4} \mathrm{O}$ : $434\left(\mathrm{M}^{+}\right)$; Anal. calcd for $\mathrm{C}_{23} \mathrm{H}_{16} \mathrm{Cl}_{2} \mathrm{~N}_{4} \mathrm{O}$ : C 63.46, H 3.70, Cl 16.29, N 12.87, O 3.68 found C 63.48, H 3.72. N 12.89, O 3.69 .

(E)-4-((4-((4-chloro-2-nitrophenylimino)methyl)-3-hydroxynaphthalen-2-yl)diazenyl) benzoic acid (NS-13) Orange color; Yield: 64\%; mp: 58-60 ${ }^{\circ} \mathrm{C}$; $\mathrm{R}_{\mathrm{f}}=0.52$ (hexane/ethyl acetate $\left.3: 2\right) ;{ }^{1} \mathrm{HNMR}(400 \mathrm{MHz}$, DMSO- $\left._{6}\right) \delta: 14.57(\mathrm{~s}, 1 \mathrm{H}), 12.99(\mathrm{~s}, 1 \mathrm{H}), 9.71(\mathrm{~s}, 1 \mathrm{H})$, $8.57(\mathrm{~d}, J=8.4 \mathrm{~Hz}, 1 \mathrm{H}), 8.48(\mathrm{~d}, J=8.4 \mathrm{~Hz}, 1 \mathrm{H}), 8.24(\mathrm{~d}$, 
$J=2.4 \mathrm{~Hz}, 1 \mathrm{H}), 8.12(\mathrm{~d}, J=2.4 \mathrm{~Hz}, 1 \mathrm{H}), 8.05(\mathrm{t}, J=8.8 \mathrm{~Hz}$, $1 \mathrm{H}), 7.85-7.98(\mathrm{~m}, 2 \mathrm{H}), 7.75(\mathrm{~d}, J=7.6 \mathrm{~Hz}, 1 \mathrm{H} 1 \mathrm{H}), 7.43-$ $7.63(\mathrm{~m}, 2 \mathrm{H}), 7.10(\mathrm{~d}, J=9.2 \mathrm{~Hz}, 1 \mathrm{H}), 6.80(\mathrm{~d}, J=9.6 \mathrm{~Hz}$, $1 \mathrm{H}) ;{ }^{13} \mathrm{C}$ NMR (100 MHz, DMSO-d $\left.{ }_{6}\right) \delta: 170.26,164.25$, $162.19,152.36,142.14,138.56,138.23,134.79,133.16$, $142.14,138.56,138.23,134.79,133.16,132.0,131.56$, $129.29,128.06,127.90,126.49,125.41,124.96,118.89$, 114.02; APCI-MS m/z found for $\mathrm{C}_{24} \mathrm{H}_{15} \mathrm{ClN}_{4} \mathrm{O}_{5}$ : 474.8 $\left(\mathrm{M}^{+}\right)$; Anal. calcd for $\mathrm{C}_{24} \mathrm{H}_{15} \mathrm{ClN}_{4} \mathrm{O}: \mathrm{C} 60.70, \mathrm{H} \mathrm{3.18,} \mathrm{Cl}$ 7.47, N 11.80, O 16.85 found C 60.72, H 3.19, N 11.83, O 16.81 .

(E)-Ethyl 2-((2-hydroxy 3-(2-nitro 4-chloro phenyldiazenyl)naphthalen-1-yl)methyleneamino)-4,5,6,7-tetrahydro benzo[b]thiophene-3-carboxylate (NS-14) Red crystals, Yield: $72 \% ; \mathrm{R}_{\mathrm{f}}=0.57$ (hexane/ethyl acetate 5:2); mp: 128 $130{ }^{\circ} \mathrm{C}$; IR (ATR, $\mathrm{cm}^{-1}$ ) $v_{\max }: 3417.23,2880.53,2518.88$, $1721.43,1630.61,1461.73,1354.60,1245.60,1115.48$, 1074.41, 930.64, 820.99, 662.00; ${ }^{1} \mathrm{H}$ NMR: $(300 \mathrm{MHz}$, $\left.\mathrm{CDCl}_{3}\right) \delta: 14.83(\mathrm{~s}, 1 \mathrm{H}), 9.30(\mathrm{~s}, 1 \mathrm{H}), 8.34(\mathrm{~s}, 1 \mathrm{H}), 8.27(\mathrm{~s}$, $1 \mathrm{H}), 8.11(\mathrm{~d}, J=9.2 \mathrm{~Hz}, 1 \mathrm{H}), 7.73-7.82(\mathrm{~m}, 1 \mathrm{H}), 7.54(\mathrm{~s}$, $1 \mathrm{H}), 7.26-7.35(\mathrm{~m}, 2 \mathrm{H}), 7.17(\mathrm{~d}, J=11.6 \mathrm{~Hz}, 1 \mathrm{H}), 4.44$ $(\mathrm{d}, J=9.2 \mathrm{~Hz}, 2 \mathrm{H}), 2.62-2.82(\mathrm{~m}, 4 \mathrm{H}), 1.61-1.84(\mathrm{~m}$, $4 \mathrm{H}), 1.42(\mathrm{t}, J=9.2 \mathrm{~Hz}, 3 \mathrm{H}) ;{ }^{13} \mathrm{C}$ NMR $\left(75 \mathrm{MHz}, \mathrm{CDCl}_{3}\right)$ $\delta: 165.29,163.55,153.66,153.16,135.94,135.79,132.68$, $130.81,129.34,127.97,127.79,123.73,123.29,122.68$, $118.43,116.67,109.55,60.77,26.34,25.58,22.91,22.55$, 14.46; APCI-MS m/z found for $\mathrm{C}_{28} \mathrm{H}_{23} \mathrm{ClN}_{4} \mathrm{O}_{5} \mathrm{~S}: 563$ $\left(\mathrm{M}^{+}\right)$; Anal. calcd for $\mathrm{C}_{28} \mathrm{H}_{23} \mathrm{ClN}_{4} \mathrm{O}_{5} \mathrm{~S}$ : C 59.73, H 4.12 $\mathrm{Cl} 6.30, \mathrm{~N} 9.95, \mathrm{O} 14.21, \mathrm{~S} 5.70$ found C 59.79, H 4.14, N 9.97, O 14.23.

3-((4-hloro-2-nitrophenyl)diazenyl)-1-((4-methylpyridin-2-ylimino)methyl)naphthalen-2-ol (NS-15) Maroon crystals, Yield: 61\%; $\mathrm{R}_{\mathrm{f}}=0.49$ (hexane/ethyl acetate 3:2); mp: $65-70{ }^{\circ} \mathrm{C}$; IR (ATR, $\mathrm{cm}^{-1}$ ) $v_{\max }$ : 3385.46, $3304.04,3236.92,3084.45,2923.61,2859.42,1724.04$, $1629.08,1462.98,1397.92,1314.26,1251.36,1171.02$, 1079.03, 972.11, 915.89, 822.63, 744.24, 624.86; ${ }^{1} \mathrm{H}$ NMR $\left(300 \mathrm{MHz}, \mathrm{CDCl}_{3}\right) \delta: 13.21(\mathrm{~s}, 1 \mathrm{H}), 9.85(\mathrm{~s}, 1 \mathrm{H}), 8.66(\mathrm{~d}$, $J=9.6 \mathrm{~Hz}, 1 \mathrm{H}), 8.54(\mathrm{~d}, J=10 \mathrm{~Hz}, 1 \mathrm{H}), 8.34(\mathrm{~d}, J=9.6 \mathrm{~Hz}$, $1 \mathrm{H}), 7.98(\mathrm{t}, J=5.6 \mathrm{~Hz}, 1 \mathrm{H}), 7.79(\mathrm{~d}, J=10 \mathrm{~Hz}, 1 \mathrm{H}), 7.59-$ 7.64 (m, 2H), 7.41-7.46 (m, 2H), 7.12-7.26 (m, 2H), 2.09 (s, 3H); ${ }^{13} \mathrm{C}$ NMR (75 MHz, $\mathrm{CDCl}_{3}$ ) $\delta: 166.27,164.50$, $160.25,158.36,147.31,145.18,142.21,139.32,135.12$, $132.65,129.48,129.12,127.79,124.51,119.17,118.55$ 116.38, 109.45; APCI-MS m/z found for $\mathrm{C}_{23} \mathrm{H}_{16} \mathrm{ClN}_{5} \mathrm{O}_{3}$ : $445\left(\mathrm{M}^{+}\right)$; Anal. calcd for $\mathrm{C}_{23} \mathrm{H}_{16} \mathrm{ClN}_{5} \mathrm{O}_{3}$ : C 61.96, H 3.62 $\mathrm{Cl} 7.95, \mathrm{~N} 15.71$, O 10.77 found C 61.93, H 3.631 N 15.68, O 10.76 .

(E)-Ethyl 2-((2-hydroxy 3-(2-chloro 4-nitro phenyldiazenyl)naphthalen-1-yl)methyleneamino)-4,5,6,7-tetrahyd robenzo[b]thiophene-3-carboxylate (NS-16) Maroon shiny crystals, Yield: $73 \% ; \mathrm{R}_{\mathrm{f}}=0.51$ (hexane/ethyl acetate 3:2); mp: $138-140{ }^{\circ} \mathrm{C}$; IR (ATR, $\mathrm{cm}^{-1}$ ) $v_{\max }$; 3457.37, $3327.03,3126.54,3029.09,2340.22,1665.15,1573.53$, $1493.45,1431.53,1325.02,1255.94,1187.72,1127.49$, 995.00, 824.71, 746.41, 653.87; ${ }^{1} \mathrm{H}$ NMR (300 MHz, $\left.\mathrm{CDCl}_{3}\right) \delta: 14.83(\mathrm{~s}, 1 \mathrm{H}), 9.30(\mathrm{~s}, 1 \mathrm{H}), 8.32(\mathrm{~s}, 1 \mathrm{H}), 8.10$ $(\mathrm{d}, J=11.2 \mathrm{~Hz}, 1 \mathrm{H}), 7.81(\mathrm{~d}, J=11.2 \mathrm{~Hz}, 1 \mathrm{H}), 7.74(\mathrm{~d}$, $J=11.2 \mathrm{~Hz}, 1 \mathrm{H}), 7.54(\mathrm{t}, J=9.6 \mathrm{~Hz}, 1 \mathrm{H}), 7.36(\mathrm{t}, J=9.6 \mathrm{~Hz}$, $1 \mathrm{H}), 7.16-7.26(\mathrm{~m}, 2 \mathrm{H}), 4.44(\mathrm{q}, J=9.6 \mathrm{~Hz}, 2 \mathrm{H}), 2.74-$ $2.82(\mathrm{~m}, 4 \mathrm{H}), 1.59-1.84(\mathrm{~m}, 4 \mathrm{H}), 1.43(\mathrm{t}, J=9.6 \mathrm{~Hz}, 3 \mathrm{H})$; ${ }^{13} \mathrm{C}$ NMR $\left(75 \mathrm{MHz}, \mathrm{CDCl}_{3}\right) \delta: 165.28,163.55,153.66$, $153.16,135.94,135.79,132.68,130.81,129.34,127.97$, $127.78,123.73,123.29,122.68,118.43,116.67,109.55$, $60.79,26.34,25.58,22.91,22.55,14.44$; APCI-MS m/z found for $\mathrm{C}_{18} \mathrm{H}_{23} \mathrm{ClN}_{4} \mathrm{O}_{5} \mathrm{~S}$ : $563\left(\mathrm{M}^{+}\right)$; Anal. calcd for $\mathrm{C}_{18} \mathrm{H}_{23} \mathrm{ClN}_{4} \mathrm{O}_{5} \mathrm{~S}$ : C 59.73, H 4.12 Cl 6.30, N 9.95, O 14.21, S 5.70 found C 59.72, H 4.11, N 6.26, O 14.23.

4-((2-Hydroxy 3(-(2-nitro 4-chloro phenyldiazenyl) naphthalen-1-yl)methyleneamino) butanoic acid (NS-21) Brown color; Yield: $70 \% ; \mathrm{R}_{\mathrm{f}}=0.41$ (hexane/ ethyl acetate $3: 2$ ); mp: $140-145{ }^{\circ} \mathrm{C}$ IR (ATR, $\mathrm{cm}^{-1}$ ) $v_{\max }: 3433.92,3352.25,3294.64,3157.07,3078.15$, $3028.37,2879.17,1673.84,1621.201595 .60,1430.35$, 1360.25, 1281.07, 1223.76, 1119.36, 1071.34, 932.88, 844.53, 766.60, 693.04, 624.04; ${ }^{1} \mathrm{H}$ NMR $(400 \mathrm{MHz}$, DMSO): $14.12(\mathrm{~s}, 1 \mathrm{H}), 12.17(\mathrm{~s}, 1 \mathrm{H}) 9.10(\mathrm{~s}, 1 \mathrm{H}), 8.43(\mathrm{~d}$, $J=8.0 \mathrm{~Hz}, 1 \mathrm{H}), 8.31(\mathrm{~s}, 1 \mathrm{H}), 8.06(\mathrm{~d}, J=8.0 \mathrm{~Hz}, 1 \mathrm{H}), 7.72$ $(\mathrm{d}, J=9.6 \mathrm{~Hz}, 1 \mathrm{H}), 7.63(\mathrm{~d}, J=7.6 \mathrm{~Hz}, 1 \mathrm{H}), 7.40-7.43(\mathrm{~m}$, $1 \mathrm{H}), 7.17-7.20(\mathrm{~m}, 1 \mathrm{H}), 6.72(\mathrm{~d}, J=9.2 \mathrm{~Hz}, 1 \mathrm{H}), 3.66(\mathrm{t}$, $J=6.8 \mathrm{~Hz}, 2 \mathrm{H}), 2.32(\mathrm{t}, J=7.2 \mathrm{~Hz}, 2 \mathrm{H}), 1.90(\mathrm{t}, J=6.8 \mathrm{~Hz}$, $2 \mathrm{H}) ;{ }^{13} \mathrm{C}$ NMR $\left(75 \mathrm{MHz}, \mathrm{CDCl}_{3}\right) \delta: 173.26,165.93$, $161.91,153.65,142.23,139.13,132.87,129.48,129.12$, $127.79,124.51,119.17,118.59,116.28,109.36,59.23$, 33.17, 26.14; APCI-MS m/z found for $\mathrm{C}_{21} \mathrm{H}_{17} \mathrm{ClN}_{4} \mathrm{O}_{5}: 440$ $\left(\mathrm{M}^{+}\right)$; Anal. calcd for $\mathrm{C}_{21} \mathrm{H}_{17} \mathrm{ClN}_{4} \mathrm{O}_{5}$; C 57.22, $\mathrm{H} 3.89 \mathrm{Cl}$ 8.04, N 12.71, O 18.15 found C 57.25, H 3.87 N 12.67, O 18.13.

4-((2-hydroxy 3-(2,5 dichlorophenyldiazenyl)naphthalen-1-yl)methyleneamino)butanoic acid (NS-22) Orange color; Yield: $74 \% ; \mathrm{R}_{\mathrm{f}}=0.48$ (hexane/ethyl acetate 5:2); mp: $140-142{ }^{\circ} \mathrm{C}$; IR (ATR, $\mathrm{cm}^{-1}$ ) $v_{\max }: 3554.29,3482.86$, $3275.53,3163.02,3043.78,2923.95,2785.48,1683.59$, $1626.14,1560.99,1490.84,1416.86,1360.38,1206.58$, 1098.88, 983.42, 867.13, 800.46, 728.61, 662.08; ${ }^{1} \mathrm{H}$ NMR $\left(300 \mathrm{MHz}, \mathrm{CDCl}_{3}\right) \delta: 14.81(\mathrm{~s}, 1 \mathrm{H}), 12.51(\mathrm{~s}, 1 \mathrm{H}), 9.21(\mathrm{~s}$, $1 \mathrm{H}), 8.51(\mathrm{~d}, J=8.0 \mathrm{~Hz}, 1 \mathrm{H}), 8.25(\mathrm{~s}, 1 \mathrm{H}), 8.12(\mathrm{~d}, J=8 \mathrm{~Hz}$, $1 \mathrm{H}), 7.77(\mathrm{~d}, J=9.6 \mathrm{~Hz}, 1 \mathrm{H}), 7.46-7.63(\mathrm{~m}, 2 \mathrm{H}), 7.13-$ $7.25(\mathrm{~m}, 1 \mathrm{H}), 6.79(\mathrm{~d}, J=9.2 \mathrm{~Hz}, 1 \mathrm{H}), 3.62(\mathrm{t}, J=7.6 \mathrm{~Hz}$, $2 \mathrm{H}), 2.52(\mathrm{t}, J=7.6 \mathrm{~Hz}, 2 \mathrm{H}), 1.95(\mathrm{t}, J=7.6 \mathrm{~Hz}, 2 \mathrm{H}) ;{ }^{13} \mathrm{C}$ NMR $\left(75 \mathrm{MHz}, \mathrm{CDCl}_{3}\right) \delta: 173.26,165.93,161.91,153.65$, 
142.23, 139.13, 132.87, 129.48, 129.12, 127.79, 124.51, $119.17,118.59,116.28,109.36,59.23,33.17,26.14$; APCIMS m/z found for $\mathrm{C}_{21} \mathrm{H}_{17} \mathrm{Cl}_{2} \mathrm{~N}_{3} \mathrm{O}_{3}: 430\left(\mathrm{M}^{+}\right)$; Anal. calcd for $\mathrm{C}_{21} \mathrm{H}_{17} \mathrm{Cl}_{2} \mathrm{~N}_{3} \mathrm{O}_{3} ; \mathrm{C} 58.62, \mathrm{H} 3.98 \mathrm{Cl} 16.48, \mathrm{~N}$ 9.77, O 11.16 found $\mathrm{C} 58.65, \mathrm{H} 3.99, \mathrm{~N} 9.79$, O 11.14.

4-((2-hydroxy 3-(4-carboxydiazenyl)naphthalen-1-yl) methyleneamino)butanoic acid (NS-23) Orange color; Yield: $77 \% ; \mathrm{R}_{\mathrm{f}}=0.49$ (hexane/ethyl acetate 3:2); mp: 134$136{ }^{\circ} \mathrm{C}$; IR (ATR, $\mathrm{cm}^{-1}$ ) $v_{\max }: 3346.74,3305.52,2847.68$, $2770.40,2265.75,1721.84,1633.06,1461.09,1411.46$, $1310.26,1252.90,1173.70,1096.01,974.77,827.65$, $752.59,666.23 .14,1560.99,1490.84,1416.86,1360.38$, 1206.58, 1098.88, 983.42, 867.13, 800.46, 728.61, 662.08; ${ }^{1} \mathrm{H}$ NMR $\left(300 \mathrm{MHz}, \mathrm{CDCl}_{3}\right.$ ) $\delta: 14.81$ (s, 1H), 11.89-12.01 $(\mathrm{m}, 2 \mathrm{H}), 8.75(\mathrm{~s}, 1 \mathrm{H}), 7.86(\mathrm{~d}, J=8 \mathrm{~Hz}, 1 \mathrm{H}), 7.59-7.68(\mathrm{~m}$, $3 \mathrm{H}), 7.22-7.47(\mathrm{~m}, 4 \mathrm{H}), 6.92(\mathrm{~d}, J=12.2 \mathrm{~Hz}, 1 \mathrm{H}), 3.72(\mathrm{t}$, $J=8.0 \mathrm{~Hz}, 2 \mathrm{H}), 2.54(\mathrm{t}, J=8.0 \mathrm{~Hz}, 2 \mathrm{H}), 2.13(\mathrm{t}, J=8.0 \mathrm{~Hz}$, $2 \mathrm{H}) ;{ }^{13} \mathrm{C}$ NMR $\left(75 \mathrm{MHz}, \mathrm{CDCl}_{3}\right) \delta: 177.26,170.25$, $164.27,163.52,153.56,151.27,135.89,135.64,132.56$, 130.70, 129.37, 127.64, 123.76, 123.14, 120.56, 116.42, 58.77, 35.33, 26.99; APCI-MS m/z found for $\mathrm{C}_{22} \mathrm{H}_{19} \mathrm{~N}_{3} \mathrm{O}_{5}$ : $405.08\left(\mathrm{M}^{+}\right)$; Anal. calcd for $\mathrm{C}_{22} \mathrm{H}_{19} \mathrm{~N}_{3} \mathrm{O}_{5}$ : C 65.18, $\mathrm{H} 4.72$, N 10.37, O 19.73 found C 65.21, H 4.74, N 10.34, O 19.76.

\section{Antimicrobial activity Determination of MIC}

The MIC values of synthesized Schiff bases were determined by tube dilution method by the reported procedure [38]. The fluconazole (antifungal) and cefotaxime (antibacterial) were used as standard drugs. The test compounds and standard drugs were dissolved in DMSO to get stock solutions of the concentration of $1000 \mu \mathrm{g} / \mathrm{ml}$. The test and standard compounds were serially diluted to different concentrations $(500,250,125,62.5,31.25$, $15.62,7.81,3.90,1.95 \mu \mathrm{g} / \mathrm{ml}$ ) in nutrient broth (for bacterial strains) and sabouraud dextrose broth (for fungal strains). The $100 \mu \mathrm{l}$ of microbial inoculum was added to each concentration of the test and standard compounds to give final inoculum size of $5 \times 10^{5}$ colony forming units (CFU) $\mathrm{ml}^{-1}$ under sterile conditions. The different tubes with various concentration of the test and standard compounds and microbial strains were incubated for the specified time (for bacterial cultures-24 h at $37 \pm 2{ }^{\circ} \mathrm{C}$; fungal cultures-7 days at $25 \pm 2{ }^{\circ} \mathrm{C}$.

\section{Determination of $M B C / M F C$}

After MIC evaluation, the synthesised derivatives NS1NS23, were further assessed for MBC and MFC values. To the sterilized petri plates, added $100 \mu$ l of culture from each test tube showing no visible growth in MIC test tubes aseptically. The $10-15 \mathrm{ml}$ of nutrient agar and
Sabouraud dextrose agar was added to the petri plates for bacterial and fungal samples respectively with gentle shaking of plates in order to mix the culture throughout the media. Allowed the media to solidify. The petri plates were then incubated for the specified time and temperature as mentioned previously for bacterial and fungal cultures respectively. The plates were then analysed visually for growth. The MBC and MFC were stated as the minimum concentration of the compounds in aliquots showing no visual growth after incubation.

\section{Cytotoxicity study \\ Cell culture}

HT-29 cell line was initially procured from the National Centre for Cell Sciences (NCCS), Pune, India, and maintained in DMEM (Dulbecco's Modified Eagle Medium). The cell line was cultured in $25 \mathrm{~cm}^{2}$ tissue culture flask with DMEM supplemented with 10\% FBS (Fetal bovine serum), L-glutamine, sodium bicarbonate and an antibiotic solution containing: penicillin $(100 \mathrm{U} / \mathrm{ml})$, streptomycin $(100 \mu \mathrm{g} / \mathrm{ml})$. The cultured cell line was kept at $37^{\circ} \mathrm{C}$ in a humidified $5 \% \mathrm{CO}_{2}$ incubator (VWR, USA).

\section{MTT cell proliferation assay}

The compounds found to have good antimicrobial potential were then screened for their cytotoxicity using MTT assay $[39,40]$. Aliquot $(200 \mu \mathrm{l})$ suspension of cells was seeded in a 96-well plate at cell density of $2 \times 10^{4}$ cells per well. The cells were incubated in a $\mathrm{CO}_{2}$ incubator for $24 \mathrm{~h}$. Afterward, test compounds were added in the desired concentrations $(5,10,15,25,50,100 \mu \mathrm{g} / \mathrm{ml})$ to the wells. Simultaneously, the culture medium without cells was used as medium control to neglect the interference from other reducing components such as cholesterol, ascorbic acid, etc, present in the medium. The culture medium without test compounds was used as a negative control. The plates were incubated for $24 \mathrm{~h}$ at $37^{\circ} \mathrm{C}$ in a $5 \% \mathrm{CO}_{2}$ atmosphere. After incubation, plates were removed and decanted off the spent medium followed by addition of MTT reagent to a final concentration of $0.5 \mathrm{mg} / \mathrm{ml}$ of total volume. The plates were again incubated for $3 \mathrm{~h}$. The MTT reagent was removed followed by addition of $100 \mu \mathrm{l}$ of solubilization solvent DMSO with stirring in a gyratory shaker. The absorbance was read on an ELISA reader at $630 \mathrm{~nm}$. The $\mathrm{IC}_{50}$ value was calculated using the linear regression equation i.e. $\mathrm{Y}=\mathrm{Mx}+\mathrm{C}$. Here, $\mathrm{Y}=50, \mathrm{M}$ and $C$ values were derived from the viability graph. The assay was performed in duplicate.

\section{Morphological study}

The HT-29 cells were exposed to the indicated concentrations of the standard and test compounds and morphological changes were monitored after $24 \mathrm{~h}$. The 
photographs were taken with an inverted phase microscope (Biolink).

\section{Apoptosis study by flow cytometer}

The induction of apoptosis by test compounds in HT-29 cells was confirmed by AV/PI staining assay using flow cytometer [41]. The cells were cultured in a 6-well plate at a density of $3 \times 10^{5}$ cells $/ 2 \mathrm{ml}$ and incubated at $37{ }^{\circ} \mathrm{C}$ for $24 \mathrm{~h}$ in a $\mathrm{CO}_{2}$ incubator. The spent medium was aspirated and the cells were treated with the $\mathrm{IC}_{50}$ concentration of the test compounds (NS-2 and NS-21) and standard, in $2 \mathrm{ml}$ of culture medium and again incubated for $24 \mathrm{~h}$. After incubation, the medium was removed from all the wells and cells were given phosphate buffer saline (PBS) wash. Afterward, $200 \mu \mathrm{l}$ of trypsin-EDTA solution was added to the cells followed by incubation at $37{ }^{\circ} \mathrm{C}$ for 3-4 min. The $2 \mathrm{ml}$ of culture medium was added to the cells and harvested directly into $12 \times 75 \mathrm{~mm}$ polystyrene tubes. The tubes were centrifuged for $5 \mathrm{~min}$ at $300 \times g$ at $25{ }^{\circ} \mathrm{C}$. The supernatant was decanted carefully. The cells were washed twice with PBS. Decant the PBS completely. $5 \mu \mathrm{l}$ of FITC Annexin-V was added. The cells were vortexed gently and incubated for $15 \mathrm{~min}$ at room temperature $\left(25^{\circ} \mathrm{C}\right)$ in the dark. $5 \mu \mathrm{l}$ of PI and $400 \mu \mathrm{l}$ of $1 \mathrm{X}$ Binding buffer was added to each tube and vortexed gently. The cells were analyzed immediately after addition of PI by flow cytometry.

\section{Cell cycle analysis}

The most frequently used dye for DNA content/cell cycle analysis is PI. It can be used to stain whole cells or isolated nuclei [42]. The cells $\left(1 \times 10^{5}\right)$ were seeded in 24 well plates and treated with the $\mathrm{IC}_{50}$ concentration of the test compounds for $24 \mathrm{~h}$. At the end time, the cells were detached by trypsin-EDTA solution at $37{ }^{\circ} \mathrm{C}$ for $5 \mathrm{~min}$. Next, the trypsin activity was stopped with adding 10\% FBS-RPMI 1640 medium. Both adherent and detached cells were collected, washed in cold PBS twice, fixed by ice-cold ethanol $(70 \% \mathrm{w} / \mathrm{w})$ and then incubated in PBS containing $0.1 \%$, Triton X-100, $0.1 \%$ sodium citrate, RNase A (50 $\mu \mathrm{g} / \mathrm{ml}$; Fermentas), and PI ( $50 \mu \mathrm{g} / \mathrm{ml}$; Sigma) at $4{ }^{\circ} \mathrm{C}$ for $30 \mathrm{~min}$. The percent of calculated cells in the sub-G1, G0/G1, S, and G2/M phases were analyzed by flow cytometry (BD FACSCalibur flow cytometer, USA).

\section{Conclusion}

In search of novel dual-action drugs having the potential for colon cancers and microbial infections both, a series of novel naphthol diazenyl scaffold containing Schiff bases was efficiently synthesized and characterized by various spectroscopic techniques. During preliminary evaluation for antimicrobial potential, the derivatives NS-2 and
NS-8 were found most active against bacterial strains E. coli, S. enterica with very low MIC and MBC values while NS-21 and NS-23 were found most active against fungal strain A. fumigatus. The derivatives showing good antimicrobial properties were further screened for their cytotoxic potential against human colorectal carcinoma cell line (HT-29). The test derivatives NS-2 and NS-21 exhibited significant cytotoxicity against HT-29 cell line with $\mathrm{IC}_{50}$ values from $4.8 \mu \mathrm{g} / \mathrm{ml}$ and $19.2 \mu \mathrm{g} / \mathrm{ml}$ respectively and further selected for evaluation of apoptosisinducing potential in HT-29 cells. In conclusion, both NS-2 and NS-21 have induced apoptosis in HT-29 cell line particularly NS-2 with more than $90 \%$ of the cells in the apoptotic phase after $24 \mathrm{~h}$ treatment as compared to $68 \%$ in case of standard drug doxorubicin. Both NS-2 and NS-21 have arrested the cells in S and G2/M phases of the cell cycle. On the basis of the above results, it is clear that these derivatives can have potential in therapeutics including treatment for both cancer and associated microbial infections simultaneously.

\section{Additional file}

Additional file 1. ${ }^{1} \mathrm{H}$ and ${ }^{13} \mathrm{C}$ NMR data of most active compounds has been provided.

\section{Abbreviations}

MIC: minimum inhibitory concentration; MBC: minimum bactericidal concentration; MFC: minimum fungicidal concentration; MTT: 3-(4,5-dimethylthiazol2-yl)-2,5-diphenyltetrazolium bromide; E. coli: Escherichia coli; S. enterica: Salmonella enterica; B. subtilis: Bacillus subtilis; S. aureus: Staphylococcus aureus; A. niger: Aspergillus niger; A. fumigatus: Aspergillus fumigatus; AV: Annexin-V; PI: propidium iodide; PS: phosphatidylserine; DMEM: Dulbecco's Modified Eagle Medium; PBS: phosphate buffer saline; FBS: fetal bovine serum.

\section{Authors' contributions}

Authors BN, and HK have designed, synthesized and carried out the biological evaluations and JS have done the interpretation of anticancer evaluation of synthesized compounds. All authors read and approved the final manuscript.

\section{Author details}

${ }^{1}$ Faculty of Pharmaceutical Sciences, Maharshi Dayanand University, Rohtak 124001, India. ${ }^{2}$ College of Pharmacy, Postgraduate Institute of Medical Sciences, Rohtak 124001, India.

\section{Acknowledgements}

The authors are thankful to Head, Department of Pharmaceutical Sciences, Maharshi Dayanand University, Rohtak, for providing necessary facilities to carry out this research work.

\section{Competing interests}

The authors declare that they have no competing interests.

Availability of data and materials

Provided as Additional file 1.

Funding

The University Grant Commission has provided SRF award to author, $\mathrm{H}$. Kaur vide award letter no. F.25-1/2013-14(BSR)/7-344/2011(BSR) to carry out this research work. 


\section{Publisher's Note}

Springer Nature remains neutral with regard to jurisdictional claims in published maps and institutional affiliations.

Received: 1 December 2018 Accepted: 15 March 2019

Published online: 02 April 2019

\section{References}

1. Bray F, Ferlay J, Soerjomataram I, Siegel RL, Torre LA, Jemal A (2018) Global cancer statistics 2018: GLOBOCAN estimates of incidence and mortality worldwide for 36 cancers in 185 countries. CA Cancer J Clin 68(6):394424. https://doi.org/10.3322/caac.21492

2. Nagai H, Kim YH (2017) Cancer prevention from the perspective of global cancer burden patterns. J Thorac Dis. 9:448-451. https://doi.org/10.21037 /jtd.2017.02.75

3. Hanahan D, Weinberg RA (2011) Hallmarks of cancer: the next generation. Cell 144:646-674. https://doi.org/10.1016/j.cell.2011.02.013

4. Benharroch D, Osyntsov L (2012) Infectious diseases are analogous with cancer. Hypothesis and implications. J Cancer. 3:117-121. https://doi. org/10.7150/jca.3977

5. Masrour-Roudsari J, Ebrahimpour S (2017) Causal role of infectious agents in cancer: an overview. Caspian J Intern Med 8:153-158. https://doi. org/10.22088/cjim.8.3.153

6. Alibek K, Bekmurzayeva A, Mussabekova A, Sultankulov B (2012) Using antimicrobial adjuvant therapy in cancer treatment: a review. Infect Agent Cancer. 7:33. https://doi.org/10.1186/1750-9378-7-33

7. Pestell RG, Rizvanov AA (2015) Antibiotics for cancer therapy. Oncotarget. 6:2587-2588. https://doi.org/10.18632/oncotarget.3388

8. Mohammed AA, Al-Zahrani AS, Sherisher MA, Alnagar AA, El-Shentenawy A, El-Kashif AT (2014) The pattern of infection and antibiotics use in terminal cancer patients. J Egypt Natl Canc Inst 26:147-152. https://doi. org/10.1016/j.jnci.2014.05.002

9. Gandomani HS, Yousefi SM, Aghajani M, Mohammadian-Hafshejani A, Tarazoj AA, Pouyesh V, Salehiniya H (2017) Colorectal cancer in the world: incidence, mortality and risk factors. Biomed Res Ther 4:1656-1675. https ://doi.org/10.15419/bmrat.v4i10.372

10. Tariq K, Ghias K (2016) Colorectal cancer carcinogenesis: a review of mechanisms. Cancer Biol Med 13:120-135. https://doi.org/10.28092/j.i ssn.2095-3941.2015.0103

11. Fearon ER, Vogelstein B (1990) A genetic model for colorectal tumorigenesis. Cell 61:759-767

12. Housman G, Byler S, Heerboth S, Lapinska K, Longacre M, Snyder N, Sarkar S (2014) Drug resistance in cancer: an overview. Cancers. 6:1769-1792. https://doi.org/10.3390/cancers6031769

13. Hammond WA, Swaika A, Mody K (2016) Pharmacologic resistance in colorectal cancer: a review. Ther Adv Med Oncol. 8:57-84. https://doi. org/10.1177/1758834015614530

14. Attiê R, Chinen LTD, Yoshioka EM, Silva MCF, de Lima VCC (2014) Acute bacterial infection negatively impacts cancer specific survival of colorectal cancer patients. World J Gastroenterol 20:13930-13935. https://doi. org/10.3748/wjg.v20.i38.13930

15. Patel HG, Tabassum S, Shaikh S (2017) E. coli sepsis: red flag for colon carcinoma-a case report and review of the literature. Case Rep Gastrointest Med. https://doi.org/10.1155/2017/2570524

16. Mughini-Gras L, Schaapveld M, Kramers J, Mooij S, Neefjes-Borst EA, van Pelt W, Neefjes J (2018) Increased colon cancer risk after severe Salmonella infection. PLOS ONE 13:e0189721. https://doi.org/10.1371/journal.pone.0189721

17. Praneenararat S (2014) Fungal infection of the colon. Clin Exp Gastroenterol 7:415-426. https://doi.org/10.2147/CEG.S67776

18. Zhang L, Song R, Gu D, Zhang X, Yu B, Liu B, Xie J (2017) The role of GLI1 for 5-Fu resistance in colorectal cancer. Cell Biosci. 7:17. https://doi. org/10.1186/s13578-017-0145-7

19. Hu T, Li Z, Gao C-Y, Cho CH (2016) Mechanisms of drug resistance in colon cancer and its therapeutic strategies. World J Gastroenterol 22:68766889. https://doi.org/10.3748/wjg.v22.i30.6876

20. Pistritto G, Trisciuoglio D, Ceci C, Garufi A, D'Orazi G (2016) Apoptosis as anticancer mechanism: function and dysfunction of its modulators and targeted therapeutic strategies. Aging (Albany NY). 8(4):603-619. https:// doi.org/10.18632/aging.100934
21. Mishra J, Drummond J, Quazi SH, Karanki SS, Shaw JJ, Chen B, Kumar N (2013) Prospective of colon cancer treatments and scope for combinatorial approach to enhanced cancer cell apoptosis. Crit Rev Oncol Hematol 86:232-250. https://doi.org/10.1016/j.critrevonc.2012.09.014

22. Hameed A, Al-Rashida M, Uroos M, Ali SA, Khan KM (2016) Schiff bases in medicinal chemistry: a patent review (2010-2015). Expert Opin Ther Pat. 27:63-79. https://doi.org/10.1080/13543776.2017.1252752

23. Kianfar AH, Fath RH (2017) Theoretical study of the structures of Schiff base compounds and thermodynamic study of the tautomerism reactions by ab initio calculations. Egypt J Petrol. 26:865-874. https://doi. org/10.1016/j.ejpe.2015.03.010

24. da Silva CM, da Silva DL, Modolo LV, Alves RB, de Resende MA, Martins CVB, Fátima A (2011) Schiff bases: a short review of their antimicrobial activities. J Adv Res. 2:1-8. https://doi.org/10.1016/j.jare.2010.05.004

25. Kaur H, Lim SM, Ramasamy K, Vasudevan M, AliShah SA, Narasimhan B (2017) Diazenyl schiff bases: synthesis, spectral analysis, antimicrobial studies and cytotoxic activity on human colorectal carcinoma cell line (HCT-116). Arabian J Chem. https://doi.org/10.1016/j.arabjc.2017.05.004

26. Rezki N, Al-Yahyawi AM, Bardaweel SK, Al-Blewi FF, Aouad MR (2015) Synthesis of novel 2,5-disubstituted-1,3,4-thiadiazoles clubbed 1,2,4-triazole, 1,3,4-thiadiazole, 1,3,4-oxadiazole and/or Schiff base as potential antimicrobial and antiproliferative agents. Molecules 20:16048-16067. https:// doi.org/10.3390/molecules200916048

27. Sztanke K, Maziarka A, Osinka A, Sztanke M (2013) An insight into synthetic Schiff bases revealing antiproliferative activities in vitro. Bioorg Med Chem 21:3648-3666. https://doi.org/10.1016/j.bmc.2013.04.037

28. Kaur H, Yadav S, Narasimhan B (2016) Diazenyl derivatives and their complexes as anticancer agents. Anticancer Agents Med Chem 16:1240-1265. https://doi.org/10.2174/1871520616666160607012042

29. Li Q, Zou P, Sun J, Chen L (2018) $O^{2}$-(2,4-dinitrophenyl)diazeniumdiolates derivatives: design, synthesis, cytotoxic evaluation and reversing MDR in MCF-7/ADR cells. Eur J Med Chem 143:732-744. https://doi.org/10.1016/j. ejmech.2017.11.081

30. Xue R, Wu J, Luo X, Gong Y, Huang Y, Shen X, Zhang H, Zhang Y, Huang Z (2016) Design, synthesis, and evaluation of diazeniumdiolate-based DNA cross-linking agents activatable by glutathione S-transferase. Org Lett 18:5196-5199. https://doi.org/10.1021/acs.orglett.6b02222

31. Kaur H, Narasimhan B (2018) Antimicrobial activity of diazenyl derivatives: an update. Curr Top Med Chem 18:3-21. https://doi.org/10.2174/15680 26618666180206093107

32. Piotto S, Concilio S, Sessa L, Diana R, Torrens G, Juan C, Caruso U, lannelli $P$ (2017) Synthesis and antimicrobial studies of new antibacterial azocompounds active against Staphylococcus aureus and Listeria monocytogenes. Molecules 22:1372. https://doi.org/10.3390/molecules22081372

33. Kelley C, Lu S, Parhi A, Kaul M, Pilch DS, Lavoie EJ (2013) Antimicrobial activity of various 4- and 5-substituted 1-phenylnaphthalenes. Eur J Med Chem 60:395-409. https://doi.org/10.1016/j.ejmech.2012.12.027

34. Medarde M, Maya AB, Pérez-Melero C (2004) Naphthalene combretastatin analogues: synthesis, cytotoxicity and antitubulin activity. J Enzyme Inhib Med Chem 19:521-540. https://doi.org/10.1080/14756360412331280473

35. Puterova Z, Krutošíková A, Végh D (2010) Gewald reaction: synthesis, properties and applications of substituted 2-aminothiophenes. ARKIVOC. 1:209-246. https://doi.org/10.3998/ark.5550190.0011.105

36. Mustroph H (1991) Studies on UVNis absorption spectra of azo dyes: part 26.1 electronic absorption spectra of $4,4^{\prime}$-diaminoazobenzenes. Dyes Pigm. 16:223-230. https://doi.org/10.1016/0143-7208(91)85012-W

37. Shabir G, Saeed A, Channar PA, Larik FA, Fatah TA (2017) Sensitive and selective "turn-on" chemodosimetric probes for $\mathrm{Fe}^{3+}$ based on a skeleton of 2-hydroxy-1-naphthaldehyde. J Fluoresc. 27:2213-2221

38. Cappucino JG, Sherman N (1999) Microbiology: a laboratory mannual. Addison Wesley Longman Inc., California, p 263

39. Morgan DML (1998) Tetrazolium (MTT) assay for cellular viability and activity. Methods Mol Biol 79:179-183

40. Mosmanni T (1983) Rapid colorimetric assay for cellular growth and survival: application to proliferation and cytotoxicity assays. J Immunol Methods 65:55-63

41. Wlodkowic D, Skommer J, Darzynkiewicz Z (2009) Flow cytometrybased apoptosis detection. Methods Mol Biol 559:19-32. https://doi. org/10.1007/978-1-60327-017-5_2

42. Pozarowski P, Darzynkiewicz Z (2004) Analysis of cell cycle by flow cytometry. Methods Mol Biol 281:301-311. https://doi.org/10.1385/1-59259-811-0:301 